NATIONAL LABORATORY

\title{
Validation of the Manufactured Home Energy Audit (MHEA)
}

\section{November 2007}

Prepared by

Mark P. Ternes

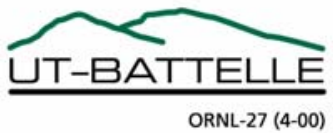




\section{DOCUMENT AVAILABILITY}

Reports produced after January 1, 1996, are generally available free via the U.S. Department of Energy (DOE) Information Bridge.

Web site http://www.osti.gov/bridge

Reports produced before January 1, 1996, may be purchased by members of the public from the following source.

National Technical Information Service

5285 Port Royal Road

Springfield, VA 22161

Telephone 703-605-6000 (1-800-553-6847)

TDD 703-487-4639

Fax 703-605-6900

E-mail info@ntis.gov

Web site http://www.ntis.gov/support/ordernowabout.htm

Reports are available to DOE employees, DOE contractors, Energy Technology Data Exchange (ETDE) representatives, and International Nuclear Information System (INIS) representatives from the following source.

Office of Scientific and Technical Information

P.O. Box 62

Oak Ridge, TN 37831

Telephone 865-576-8401

Fax 865-576-5728

E-mail reports@osti.gov

Web site http://www.osti.gov/contact.html

This report was prepared as an account of work sponsored by an agency of the United States Government. Neither the United States Government nor any agency thereof, nor any of their employees, makes any warranty, express or implied, or assumes any legal liability or responsibility for the accuracy, completeness, or usefulness of any information, apparatus, product, or process disclosed, or represents that its use would not infringe privately owned rights. Reference herein to any specific commercial product, process, or service by trade name, trademark, manufacturer, or otherwise, does not necessarily constitute or imply its endorsement, recommendation, or favoring by the United States Government or any agency thereof. The views and opinions of authors expressed herein do not necessarily state or reflect those of the United States Government or any agency thereof. 
Engineering Science and Technology Division

\title{
VALIDATION OF THE MANUFACTURED HOME ENERGY AUDIT (MHEA)
}

\author{
Mark P. Ternes
}

Date Published: November 2007

\author{
Prepared by \\ OAK RIDGE NATIONAL LABORATORY \\ Oak Ridge, Tennessee 37831-6283 \\ managed by \\ UT-BATTELLE, LLC \\ for the \\ U.S. DEPARTMENT OF ENERGY \\ under contract DE-AC05-00OR22725
}




\section{CONTENTS}

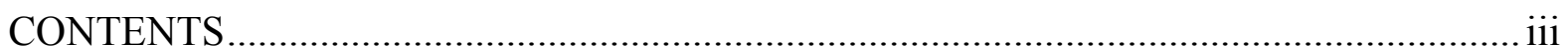

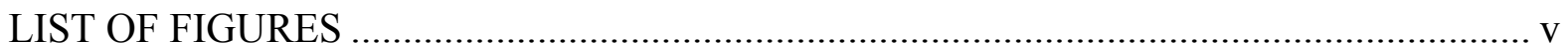

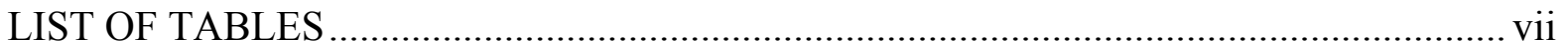

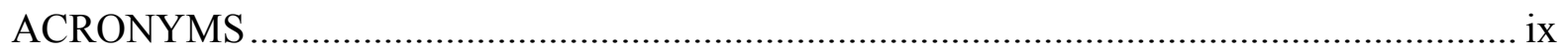

ACKNOWLEDGEMENTS .................................................................................. xi

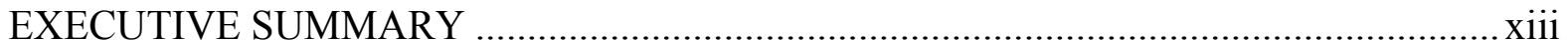

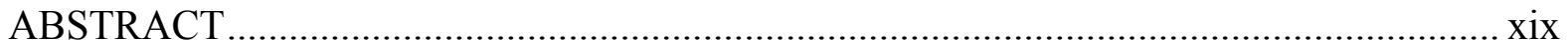

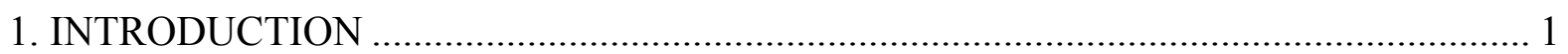

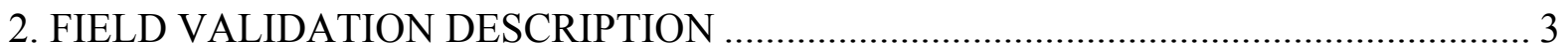

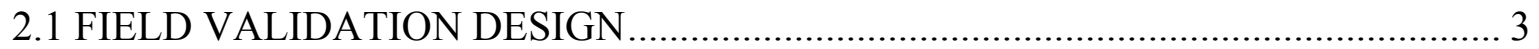

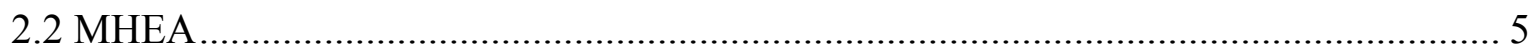

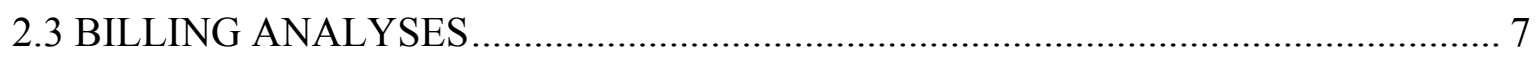

2.3.1 Primary Space-Heating Fuel ........................................................................... 7

2.3.2 Supplemental Space-Heating Electricity Use .................................................. 9

3. MOBILE HOME AND WEATHERIZATION CHARACTERISTICS ........................... 11

3.1 MOBILE HOME CHARACTERISTICS …........................................................ 11

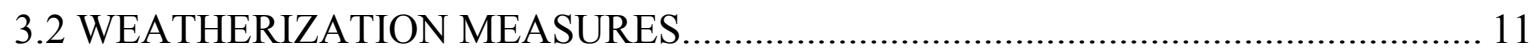

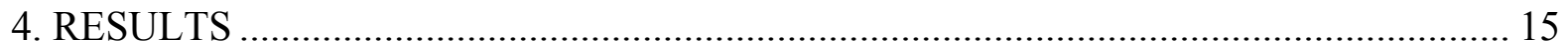

4.1 ANNUAL SPACE-HEATING ENERGY CONSUMPTIONS AND SAVINGS ........ 15

4.1.1 Accuracy Expectations and Limitations ........................................................... 15

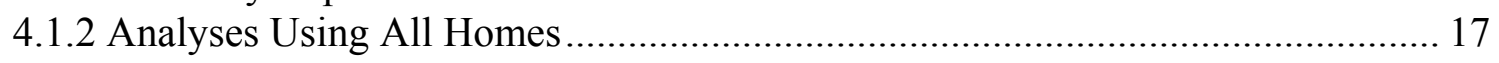

4.1.3 Analyses Using a Refined Dataset ........................................................... 22

4.1.4 Comparison with Previous Validations ........................................................... 23

4.2 ENHANCEMENTS TO IMPROVE ENERGY PREDICTION PERFORMANCE .... 24

4.2.1 Billing Adjustment Feature............................................................................ 24

4.2.2 Tune-Up and Setback Thermostat Measures ............................................... 26

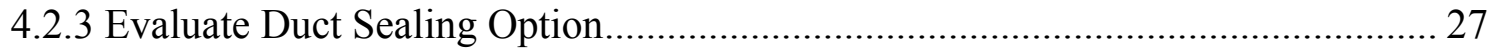

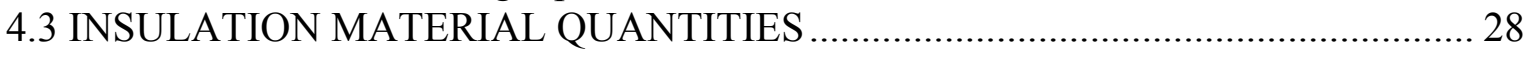

5. CONCLUSIONS AND RECOMMENDATIONS ................................................. 31

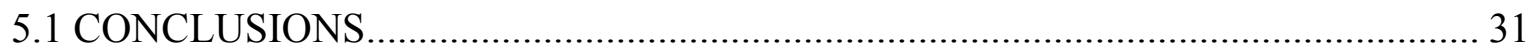

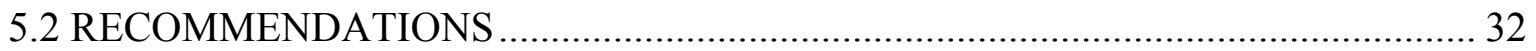

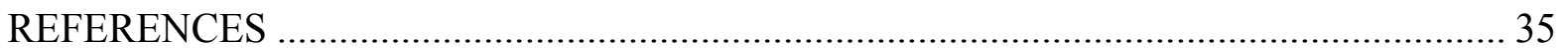




\section{LIST OF FIGURES}

ES.1. Results for individual mobile homes. Figures ES.1(a) to (c) compare MHEA's annual space-heating energy consumption and savings estimates to actual values, while Fig. ES.1(d) shows realization rates as a function of actual annual spaceheating energy savings. The solid lines are the lines of agreement between estimated and actual values, and the dashed lines in Figs. ES.1(a) and (b) were drawn arbitrarily to identify mobile homes in which the overestimation

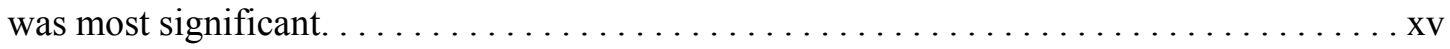

2.1. States and number of agencies participating in the field validation. $\ldots \ldots \ldots \ldots \ldots \ldots$

3.1. Distribution of pre-weatherization air leakage rates. $\ldots \ldots \ldots \ldots \ldots \ldots \ldots \ldots \ldots$

4.1. Annual space-heating energy savings as a function of annual pre-weatherization space-heating energy consumption, both based on the primary space-heating fuel only, for all homes. . . . . . . . . . . . . . . . . . . . . . 19

4.2. Comparisons of MHEA's annual space-heating energy consumption and savings estimates to actual values (based on the primary space-heating fuel only) using all homes. The solid lines are the lines of agreement between estimated and actual values. . . . . 20

4.3. Realization rate as a function of actual annual space-heating energy savings and actual annual pre-weatherization space-heating energy consumption (based on the primary space-heating fuel only) using all homes. . . . . . . . . . . . . . . . . . 21

4.4. Comparison of MHEA's estimated annual space-heating energy savings to actual savings for homes in the refined dataset with and without the use of MHEA's billing adjustment feature. The solid lines are the lines of agreement between estimated and actual values. . . . . . . . . . . . . . . . . . . . . . . . 25

4.5. Realization rate as a function of actual annual space-heating energy savings for homes in the refined dataset with and without the use of MHEA's billing

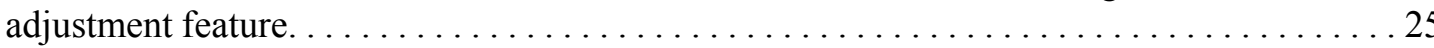

4.6. Comparison of MHEA's estimates of the amount of insulation needed to insulate the envelope area to the amount the weatherization crews actually installed. The solid lines are the lines of agreement between estimated and actual values.

The dashed lines represent estimates $25 \%$ above and below actual. . . . . . . . . . . . . 30 


\section{LIST OF TABLES}

ES.1. Annual space-heating energy consumption and savings results. $\ldots \ldots \ldots \ldots \ldots \ldots \ldots$ xiv

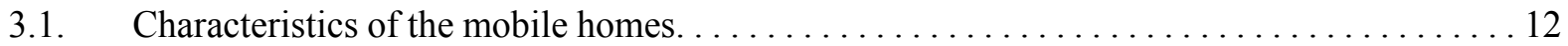

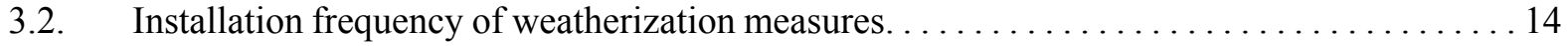

4.1. Impact of energy consumption uncertainties on potential realization rates. $\ldots \ldots \ldots \ldots \ldots 16$

4.2. Comparison of MHEA estimates to actual space-heating energy consumptions and savings ... 18

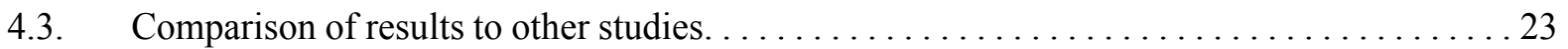

4.4. Results for the refined dataset with and without billing adjustment. . . . . . . . . . . . 24

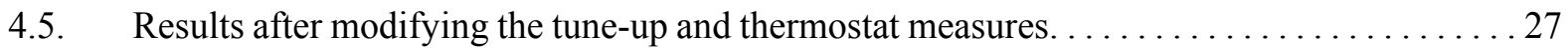

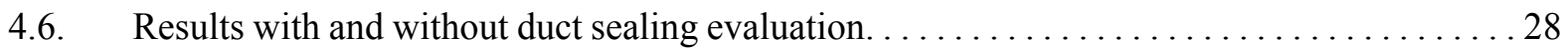

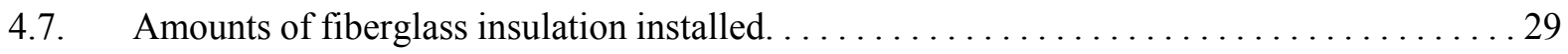




\section{ACRONYMS}

$\begin{array}{ll}\text { DOE } & \text { U.S. Department of Energy } \\ \text { MHEA } & \text { Manufactured Home Energy Audit } \\ \text { NAC } & \text { Normalized annual consumption } \\ \text { NAHC } & \text { Normalized annual heating consumption } \\ \text { NEAT } & \text { National Energy Audit } \\ \text { NOAA } & \text { National Oceanic and Atmospheric Administration } \\ \text { NREL } & \text { National Renewable Energy Laboratory } \\ \text { ORNL } & \text { Oak Ridge National Laboratory } \\ \text { PRISM } & \text { Princeton Scorekeeping Method } \\ \text { TMY } & \text { Typical Meteorological Year }\end{array}$




\section{ACKNOWLEDGEMENTS}

The author would like to acknowledge the contributions made by the 5 states and 11 agencies that volunteered to participate in the field validation. In addition to identifying mobile homes for the validation and weatherizing the homes following their standard protocols, agency personnel collected the field data necessary to run the Manufactured Home Energy Audit (MHEA), provided information on the weatherization measures installed, and obtained the billing data necessary to perform the energy analyses. This field validation would not have been possible without their efforts. The states, agencies, and staff that contributed to this validation are:

- $\quad$ Missouri (Ted Koenig)

- Missouri Ozarks Community Action, Inc. (Skip Sears and Tonya Foster)

- North Dakota (Cal Steiner and Howard Sage)

- Dickinson Community Action Partnership (Darwin Volk)

- Minot Community Action Opportunities, Inc. (John Meyer and Brent Doelbean)

- Red River Valley Community Action Partnership (Chris Loveless)

- Williston Community Action Partnership (Wayne Soiseph and Wayne Long)

- Ohio (Tim Lenahan, Tom Andrews, Dennis Biddle, and Nick Milano)

- Community Action Council of Portage County (Chris Graham)

- Community Action Organization of Delaware, Madison, and Union Counties, Inc. (Todd Michael)

- Kno-Ho-Co Ashland Community Action Commission (Larry Vickers)

- Virginia

- Community Housing Partners Corporation, New River Valley Weatherization (Lil Weston, Anthony Cox, and Bill Beachy)

- Wisconsin (Martha Benewicz)

- Hartford Community Development Authority (Tim Clarenback and Jeff Thompson)

- Indianhead Community Action Agency (Jerry Estreen and Jack Hartwig)

The author would also like to thank Scott Pigg, Energy Center of Wisconsin, who helped provide and review MHEA data files and information on weatherization measures installed for the mobile homes included in the validation from Wisconsin. 


\section{EXECUTIVE SUMMARY}

The Manufactured Home Energy Audit (MHEA) is an energy audit tool designed specifically to identify recommended weatherization measures for mobile homes as part of the U.S. Department of Energy's (DOE's) Weatherization Assistance Program. At DOE's request, a field validation of MHEA was performed to assess the audit's accuracy and the validity of its recommendations.

The field validation was performed using 86 mobile homes located in 5 northern/midwestern states and served by 11 different local weatherization agencies. The primary space-heating fuels used in the selected homes were natural gas, electricity, or propane. Homes were weatherized between April 2003 and March 2005. Billing/delivery data were collected for at least a year before and a year after weatherization, with multiple years of pre- and post-weatherization billing data collected for many homes (especially those heated by propane). The billing data were analyzed using the Princeton Scorekeeping Method (PRISM) to determine actual pre- and post-weatherization annual spaceheating energy consumptions and energy savings. These actual values were then compared to MHEA's estimated values to determine the accuracy of MHEA's calculations. MHEA also estimates space-cooling energy use and savings, but these were not evaluated in the field validation.

Most of the mobile homes were heated primarily by natural gas (57\%), while about equal numbers were heated primarily by either electricity or propane. The average floor area of the mobile homes was $939 \mathrm{ft}^{2}$, ranging in size from $500 \mathrm{ft}^{2}$ up to $1680 \mathrm{ft}^{2}$ for a double-wide unit. On average, the mobile homes had 4.2 in. of insulation in the ceiling, 2.0 in. in the floor, and $2.8 \mathrm{in.}$ in the walls. However, many of the mobile homes had $1 \mathrm{in.} \mathrm{or} \mathrm{less} \mathrm{of} \mathrm{insulation} \mathrm{in} \mathrm{the} \mathrm{ceiling,} \mathrm{floor,} \mathrm{or} \mathrm{walls.} \mathrm{This} \mathrm{was}$ especially true for floors, where $44 \%$ of the homes had $1 \mathrm{in}$. or less of insulation in the wing or belly areas of the floor. Ceilings had $1 \mathrm{in}$. or less of insulation in $15 \%$ of the homes, and walls had $1 \mathrm{in}$. or less of insulation in just $5 \%$ of the homes. The windows in $36 \%$ of the mobile homes were predominantly single-pane without storm windows. The average pre-weatherization air leakage rate of the mobile homes was $2495 \mathrm{cfm} 50$, with about a quarter of the mobile homes having an air leakage rate greater than $3000 \mathrm{cfm} 50$, and about $40 \%$ having an air leakage rate of less than $2000 \mathrm{cfm} 50$.

Three states selected weatherization measures for the mobile homes using their current audit methods, and two states used MHEA's recommendations. Air and duct sealing were performed in almost all the mobile homes. Floor insulation was performed in a majority of the homes $(87 \%)$ and was installed more frequently than ceiling insulation (52\%) and wall insulation (10\%). Half of the homes received a new door(s), and at least one window (likely more) was replaced or received a storm window in slightly less than half of the homes A new heating system and a setback thermostat were installed and a heating-system tune-up was performed in about $20 \%$ of the mobile homes, predominantly in homes heated primarily by natural gas or propane. Remaining measures installed in the mobile homes primarily dealt with baseload energy use: water heating, refrigerators, and lighting. However, three homes did receive measures that impacted air-conditioning electricity use: one home received a new air conditioning system and the existing air conditioner was tuned in two homes.

Although not a principal purpose of the evaluation, the average annual space-heating energy savings measured in the mobile homes was $13.8 \mathrm{MBtu}$, or about $20 \%$ of the average annual preweatherization space-heating energy consumption of the homes. For the validation of MHEA, the importance of these savings is to indicate that high-impact weatherization measures were installed in the mobile homes used in this study, and that these measures produced appreciable energy savings that could be estimated by MHEA (i.e., the validation was not performed using measures that produced small savings that would have been difficult to estimate). 
Table ES.1. Annual space-heating energy consumption and savings results

\begin{tabular}{|c|c|c|c|c|}
\hline \multirow[b]{2}{*}{ Group of homes } & \multicolumn{3}{|c|}{ MHEA overprediction of: } & \multirow[b]{2}{*}{ Realization rate } \\
\hline & $\begin{array}{c}\text { Pre- } \\
\text { weatherization } \\
\text { energy } \\
\text { consumption }\end{array}$ & $\begin{array}{c}\text { Post- } \\
\text { weatherization } \\
\text { energy } \\
\text { consumption }\end{array}$ & Energy savings & \\
\hline \multicolumn{5}{|c|}{ All Mobile Home (no billing adjustment) } \\
\hline All fuels & $33.0 \%$ & $-1.5 \%$ & $195.8 \%$ & $33.8 \%$ \\
\hline $\begin{array}{l}\text { Two or more } \\
\text { energy problems }\end{array}$ & $55.1 \%$ & $3.7 \%$ & $267.3 \%$ & $27.2 \%$ \\
\hline $\begin{array}{l}\text { Only one or no } \\
\text { energy problems }\end{array}$ & $18.7 \%$ & $-4.9 \%$ & $141.8 \%$ & $41.4 \%$ \\
\hline \multicolumn{5}{|c|}{ Refined Dataset } \\
\hline $\begin{array}{l}\text { All fuels (no billing } \\
\text { adjustment) }\end{array}$ & $32.6 \%$ & $-7.4 \%$ & $185.9 \%$ & $35.0 \%$ \\
\hline $\begin{array}{l}\text { All fuels (with } \\
\text { billing adjustment) }\end{array}$ & & & $87.8 \%$ & $53.2 \%$ \\
\hline
\end{tabular}

Based on an analysis of the primary space-heating fuel data for all 86 homes (see Table ES.1), MHEA overpredicted the annual pre-weatherization space-heating energy consumption by $33.0 \%$ but predicted the annual post-weatherization space-heating energy consumption fairly accurately (underprediction of 1.5\%). As a result, MHEA overestimated the annual space-heating energy savings by $195.8 \%$ and achieved an average realization rate of just $33.8 \%$ (the realization rate is the amount of energy savings realized compared to predicted, equal to the actual savings divided by the predicted savings and expressed as a percentage). Analyses using a refined dataset (homes in which PRISM's analysis results passed select reliability criteria and in which electricity billing data were collected so that supplemental space-heating electricity consumption could be calculated and added to the spaceheating consumption of the primary space-heating fuel) showed little differences in the overall results (see Table ES.1).

Figure ES.1 compares MHEA's estimates of annual pre- and post-weatherization space-heating energy consumptions and annual space-heating energy savings to measured values. MHEA's overestimation of annual pre-weatherization space-heating energy consumption is evident from Fig. ES.1(a), while Fig. ES.1(c) shows that MHEA overpredicted the annual space-heating energy savings on almost all the mobile homes. As shown in Fig. ES.1(d), most of the realization rates for individual mobile homes were between $0 \%$ and $100 \%$, with the heaviest concentration in the $0 \%$ to $50 \%$ range.

An analysis revealed that MHEA overpredicted the annual pre-weatherization space-heating energy consumption of 31 homes with two or more major energy efficiency problems by $55.1 \%$, while the overprediction was only $18.7 \%$ for the remaining 55 homes with one or no major energy efficiency problems (see Table ES.1). A major energy efficiency problem was defined as a home having:

- 1 in. or less of insulation in the ceiling of the mobile home structure,

- $1 \mathrm{in}$. or less of insulation in the floor of the mobile home structure,

- 1 in. or less of insulation in the wall of the mobile home structure,

- 1 in. or less of insulation in any envelope area (ceiling, floor, or wall) of an addition,

- A majority of single-pane windows without storms,

- An air leakage rate greater than $3000 \mathrm{cfm} 50$, or

- A space-heating steady-state efficiency of less than $70 \%$. 


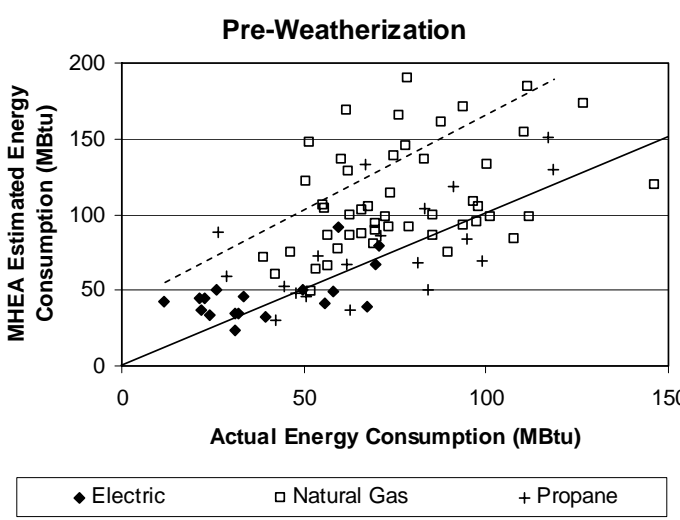

(a)

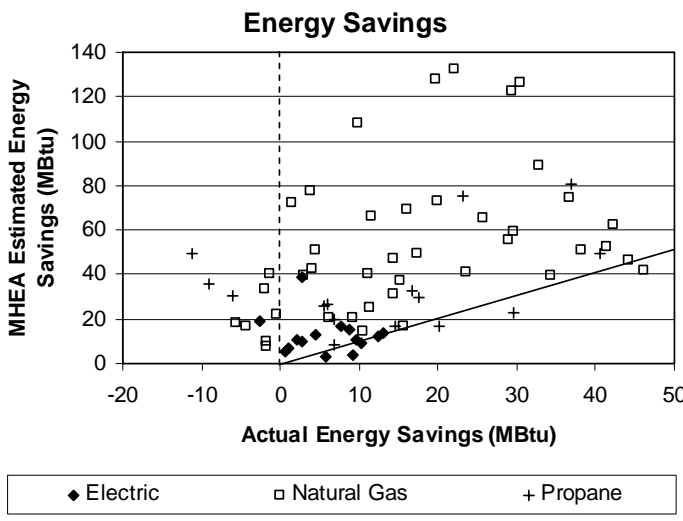

(c)

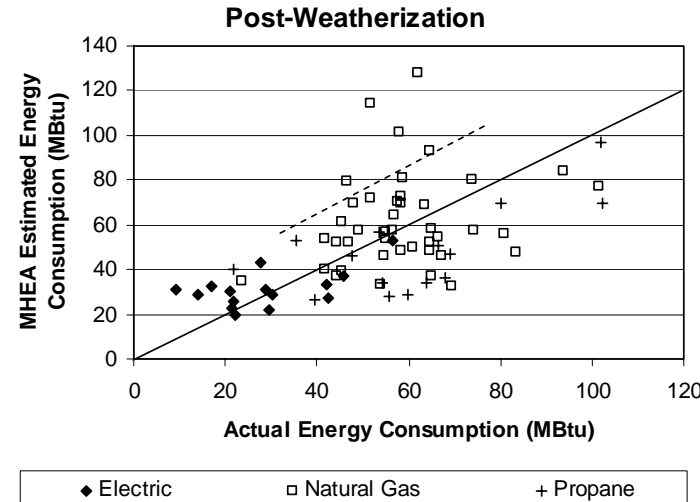

(b)

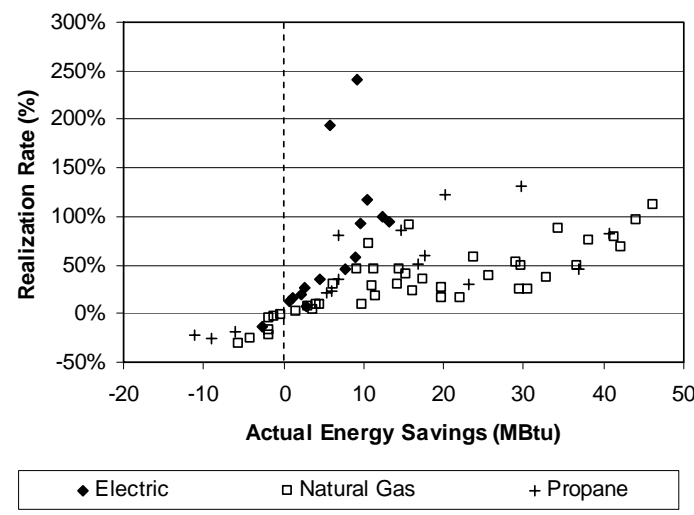

(d)

Figure ES.1. Results for individual mobile homes. Figures ES.1(a) to (c) compare MHEA's annual spaceheating energy consumption and savings estimates to actual values, while Fig. ES.1(d) shows realization rates as a function of actual annual space-heating energy savings. The solid lines are the lines of agreement between estimated and actual values, and the dashed lines in Figs. ES.1(a) and (b) were drawn arbitrarily to identify mobile homes in which the overestimation was most significant.

Because MHEA predicted the annual post-weatherization space-heating energy consumptions of the two groups of homes with and without major energy efficiency problems fairly accurately, the average realization rate of $41.4 \%$ for the homes with one or no major energy efficiency problems was significantly higher than that for the group of homes with two or more problems $(27.2 \%)$.

As shown in Table ES.1, use of MHEA's optional billing adjustment feature significantly improved, on average, MHEA's annual space-heating energy savings estimates and realization rates. This feature uses billing data entered into MHEA to adjust annual space-heating energy savings estimates based on the ratio between MHEA's estimated annual pre-weatherization space-heating energy consumption and actual consumption. MHEA's overprediction of annual space-heating energy savings for homes in the refined dataset was reduced from $185.9 \%$ to $87.8 \%$, and the realization rate for these homes increased from $35.0 \%$ to $53.2 \%$. 
An investigation was performed to determine if MHEA's "evaluate duct sealing" option improves MHEA's prediction capabilities. MHEA does not presently assume any default heat loss from duct leakage. Therefore, when the "evaluate duct sealing" option is used, MHEA calculates a higher heating load for the home because of the added duct losses, which only adds to the overprediction of annual pre-weatherization space-heating energy consumption that MHEA is already experiencing.

MHEA's estimates of the amount of insulation that needed to be installed in the floors, attic, and walls of the mobile homes were underestimated by less than $10 \%$ for both attic and wall insulation, and for insulation installed in floors with flat bellies. For floors with a rounded belly, MHEA underpredicted the amount of insulation actually installed by $22.3 \%$.

The primary conclusions drawn from this validation of MHEA are that:

- MHEA overpredicts the annual space-heating energy savings of weatherization measures to be installed in mobile homes, which leads to low realization rates.

- MHEA's large overprediction of annual pre-weatherization space-heating energy consumption is the primary cause of its overprediction of annual space-heating energy savings.

- MHEA's annual post-weatherization space-heating energy consumptions estimates are considerably more accurate than its pre-weatherization estimates and are just a secondary cause (if any) of its overprediction of annual space-heating energy savings.

- MHEA's annual space-heating energy savings estimates and realization rates can be improved considerably using MHEA's built-in billing adjustment feature.

- The use of MHEA's “evaluate duct sealing” option does not improve MHEA's prediction capabilities at this time.

- MHEA's estimates for the amount of insulation to be installed in floors, attics, and walls appear to be within reason.

The following recommendations are made based on the validation results:

- In order to improve the accuracy of MHEA's annual space-heating energy savings estimates and MHEA's realization rate, the cause of MHEA's overprediction of annual preweatherization space-heating energy consumption should be further investigated and corrected. This investigation should focus first on factors that might be associated with homes with several major energy deficiencies, such as the variable-based degree-day method used in MHEA and the R-value of building components when there is little or no insulation present and/or when the thermal integrity of the component is poor.

- Although MHEA's billing adjustment feature improved MHEA's annual space-heating energy savings estimates, alternative methods of making the correction should be investigated. A method that considers the annual post-weatherization space-heating energy consumption estimate and how it compares to the actual annual pre-weatherization spaceheating energy consumption based on billing data may provide greater capabilities. 
- Weatherization crews should be trained to use MHEA's estimates for the amounts of insulation that need to be installed in floors, attics, and walls as guidance during the insulation process. MHEA's estimates should also be used as a quality assurance check once the work is completed to ensure that the crews are using the proper techniques to install the proper amounts of insulation.

Finally, the following recommendations are offered to current users of MHEA in the interim period before the changes recommended above can be made:

- Do not enter into MHEA insulation thicknesses of 1 in. or less and especially zero (0 in.) unless such low levels have been verified through visual inspection of several parts of the envelope area in question. Such values should not be entered to account for existing floor insulation that was ripped and/or missing in some locations. Use a thickness of 1.25 in. or 1.5 in. for existing insulation blankets or batts that appear to be about 1 in. thick.

- Use MHEA's billing adjustment feature to develop a list of recommended measures based on adjusted energy savings if possible, especially in mobile homes that have two or more major energy deficiencies.

- Do not use MHEA's “evaluate duct sealing" option at this time (although certainly seal all duct leaks and use diagnostics as appropriate to find leakage sites and quantify improvements). 
xviii 


\begin{abstract}
The Manufactured Home Energy Audit (MHEA) is an energy audit tool designed specifically to identify recommended weatherization measures for mobile homes as part of the U.S. Department of Energy's (DOE's) Weatherization Assistance Program. A field validation of MHEA was performed using billing/delivery data collected on 86 mobile homes heated primarily by electricity, natural gas, or propane to assess the audit's accuracy and the validity of its recommendations. The validation found that MHEA overpredicts the annual space-heating energy savings of weatherization measures to be installed in mobile homes, which leads to low realization rates, primarily because of its large overprediction of annual pre-weatherization space-heating energy consumption. However, MHEA's annual space-heating energy savings estimates and realization rates can be improved considerably using MHEA's built-in billing adjustment feature. In order to improve the accuracy of MHEA's annual space-heating energy savings estimates and realization rate, the cause of MHEA's overprediction of annual pre-weatherization space-heating energy consumption needs to be further investigated and corrected. Although MHEA's billing adjustment feature improved MHEA's annual space-heating energy savings estimates, alternative methods of making the correction that may provide improved performance should be investigated. In the interim period before permanent improvements to MHEA can be made, the following recommendations should be followed: (a) do not enter into MHEA insulation thicknesses of $1 \mathrm{in.}$ or less and especially zero $(0 \mathrm{in}$.) unless such low levels have been verified through visual inspection of several parts of the envelope area in question; (b) use MHEA's billing adjustment feature to develop a list of recommended measures based on adjusted energy savings if possible, especially in mobile homes that have several major energy deficiencies; and (c) do not use MHEA's "evaluate duct sealing” option at this time (although certainly seal all duct leaks and use diagnostics as appropriate to find leakage sites and quantify improvements).
\end{abstract}




\section{INTRODUCTION}

The Weatherization Assistant (Gettings 2006) is an energy audit tool developed by the Oak Ridge National Laboratory (ORNL) for use in the U.S. Department of Energy's (DOE's) Weatherization Assistance Program. The Weatherization Assistant serves as an umbrella program for two specific energy audits: the National Energy Audit (NEAT) for site-built single-family homes and the Manufactured Home Energy Audit (MHEA) for mobile homes. The Weatherization Assistant also provides tools for administering and implementing a weatherization program; these tools include a system for tracking the status of clients, audits, and weatherization jobs; a feature that allows work orders to be created and updated; and a mechanism to link electronic photographs to clients, audits, and work orders.

The National Renewable Energy Laboratory (NREL) was the initial developer of MHEA. In 2001, DOE asked ORNL to incorporate a DOS version of MHEA into the Windows-based Weatherization Assistant umbrella. ORNL added new features to MHEA that made the program more user-friendly, modified some of the algorithms in MHEA to improve prediction capabilities, and expanded its functionality using features that were already included in NEAT. These changes were made based on input received from a steering committee comprised of DOE, state, and weatherization agency personnel knowledgeable in the weatherization of mobile homes. DOE released the upgraded version of MHEA to the weatherization community in September 2003 (DOE 2003) with plans to conduct a field validation of MHEA once a number of states had an opportunity to become familiar with the program. DOE stated: "Field validation of MHEA is an important and necessary part of MHEA's adoption by the weatherization network. A validation program that assesses the audit's accuracy and the validity of its recommendations will help to identify and resolve any remaining issues with MHEA's performance as it goes into widespread use."

This report presents the findings of the MHEA field validation. The primary goal of the field validation was to evaluate the overall performance of MHEA's space-heating energy-related algorithms (in aggregate rather than individually) by determining the accuracy of its preweatherization, post-weatherization, and energy savings predictions. Although MHEA also estimates space-cooling energy use and savings, these were not evaluated in the field. A secondary goal of the field validation was to compare insulation quantities estimated by MHEA to actual amounts of insulation installed by weatherization crews as a check on both the accuracy of MHEA's recommendations as well as the performance of the crews (i.e., to see if crews might be installing too much or too little insulation and, thus, if training had been effective).

Although not designed for this purpose, the information collected under the field validation may be useful in determining the overall energy savings and cost effectiveness of mobile home weatherization.

Although there have not been any previous field validations of MHEA, two studies have been performed to validate NEAT (Dalhoff 1996 and Gettings et al. 1998). Although NEAT and MHEA are two separate programs, there are many similarities between their data inputs and calculation approaches that make this comparison reasonable. Comparison of the findings from this validation of MHEA will be compared to previous findings for NEAT in Sect. 4.1.4. 


\section{FIELD VALIDATION DESCRIPTION}

The MHEA field validation was performed using 86 mobile homes located in 5 states and served by 11 different local weatherization agencies. Homes were weatherized between April 2003 and March 2005. Billing data were collected for at least a year before and a year after weatherization, with multiple years of pre- and post-weatherization billing data collected for many homes (especially those heated by propane). The billing data were analyzed to determine actual pre- and post-weatherization annual space-heating energy consumptions and energy savings. These actual values were then compared to MHEA's estimated values to determine the accuracy of MHEA's calculations. Details of the field validation design, data collection, and analysis procedures are presented in this section.

\subsection{FIELD VALIDATION DESIGN}

DOE desired the field validation to be implemented by voluntary participation of states and weatherization agencies. As shown in Figure 2.1, 11 agencies from 5 states participated. Each agency determined the number of mobile homes it could include in the field validation based on the availability of mobile homes within its service area and/or on its waiting list, its production schedule, the availability of personnel to collect the extra data required for the validation, and other factors. In Wisconsin, the field validation was coordinated with a study the state was already conducting that involved the use of MHEA.

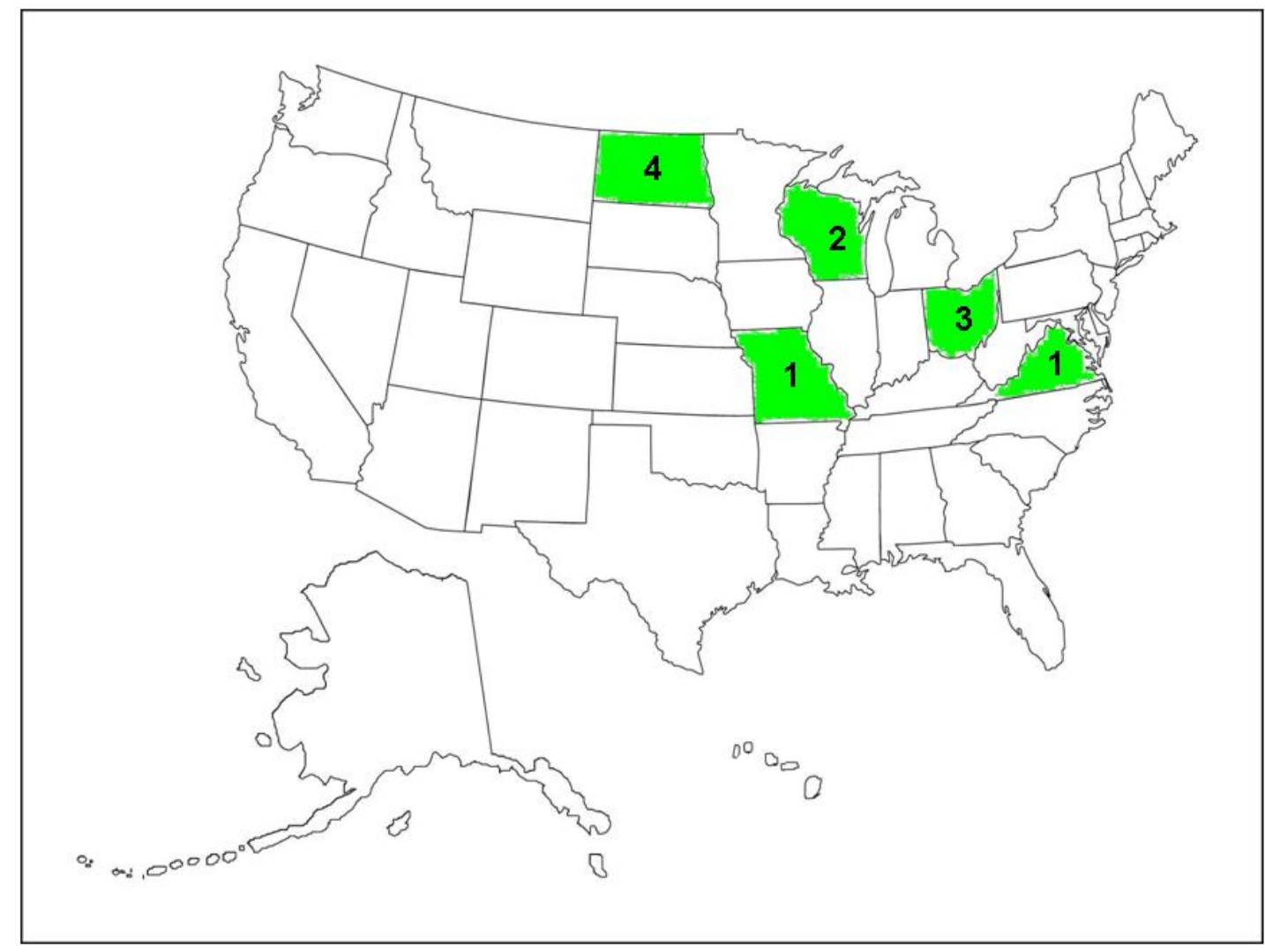

Figure 2.1. States and number of agencies participating in the field validation. 
The 5 states and 11 agencies initially identified 122 mobile homes for the validation. Four of the 11 agencies could only provide between 1 to 3 mobile homes, while the remaining 7 agencies provided between 7 to 36 mobile homes each. Collectively, each state provided between 7 to 50 mobile homes. The homes were initially screened to include only those that used natural gas, electricity, or propane as their primary space-heating fuel. The homes were also screened to exclude those that:

- Used significant amounts of supplemental space heating (wood, electricity, kerosene, etc.),

- Had additions that exceeded $25 \%$ of the original mobile home floor area,

- Had a space-heating system that was broken or replaced in the 12 months preceding weatherization,

- Had occupants who had not lived in the mobile home for the 12 months preceding weatherization, and

- Had occupants who were planning on moving within 12 months following weatherization.

Thirty-six homes were dropped from the study (none from the 4 agencies that could only provide between 1 to 3 mobile homes), leaving 86 mobile homes for the final analyses presented in Sects. 3 and 4 . Half of the homes were dropped because billing data could not be collected (primarily because a fuel-release form signed by the occupants was not available). Another 10 mobile homes were dropped because the agencies discovered later that the homes used wood or some other supplemental heating fuel (6 homes) or because blower door data were not available for use in MHEA (4 homes). In the end, each state provided between 7 to 23 mobile homes, with no individual agency providing more than 19 homes. Characteristics of the 86 mobile homes used in the study are presented in Sect. 3.1 .

A pre- and post-weatherization experimental design was used in the validation. Agencies weatherized the mobile homes between April 2003 and March 2005 (most were weatherized in 2004). Billing data on the primary space-heating fuel were collected for at least a year and usually for several years before weatherization, sometimes going back as far as 2000. Billing data on the primary spaceheating fuel were also collected for at least a year after weatherization, with some data being collected as late as May 2007. For mobile homes heated primarily by propane, special efforts were made to collect multiple years of pre- and post-weatherization billing (delivery) data as explained in Sect. 2.3.1.

In addition to the billing data collected on the primary space-heating fuel, the following data were also collected on each mobile home included in the validation:

- Input data necessary to run MHEA, including nameplate data on the space-heating system (to estimate steady-state efficiency) and pre- and post-weatherization blower door readings;

- Measured steady-state efficiencies of existing space-heating systems to supersede nameplatebased values (optional);

- Pre- and post-weatherization pressure pan readings to be used to quantify duct leakage in MHEA (optional);

- Weatherization dates;

- List of measures installed in each mobile home;

- Quantity of insulation installed in floors, ceilings, and walls (optional);

- Material and/or labor costs/hours associated with each measure installed (optional);

- Fuel used for water heating (optional); and

- Pre- and post-weatherization electric billing data on mobile homes that were heated primarily by natural gas or propane (optional). 
In three of the five states, agencies collected the field data necessary to run MHEA when they audited the mobile homes but installed measures as recommended by their current audit methods and protocols. In the remaining two states, measures were installed based primarily on the recommendations provided by MHEA. The measures actually installed in the mobile homes are described in Sect. 3.2. As discussed in Sect. 2.2, MHEA was rerun on each home from all five states after the input values were checked so that estimates of post-weatherization space-heating energy consumption and energy savings were based just on the actual measures installed. Thus, the audit or justification used to select the measures actually installed was not important in validating the accuracy of MHEA's predictions.

A control group was not included in the field validation design because the gross energy savings of the mobile homes due to the measures installed (in addition to pre- and post-weatherization energy consumptions) was the value of interest to be compared to MHEA's estimated energy savings rather than the net savings. Control groups and net savings are often used in evaluating the energy savings attributable to a weatherization program to account for effects that would have occurred if the program being evaluated did not exist. For the field validation, such a correction was not desired.

\subsection{MHEA}

Version 7.4.3.3 of MHEA was used in this field validation. This version was the current version at the time field data were collected and initially entered into MHEA. Version 8 was developed after the field validation was initiated, with Version 8.2.7.8 being the current version released to the weatherization community at the time this report was published. Version 8 was not used in the analyses because the database file associated with Version 7 cannot be uploaded into Version 8; thus, use of Version 8 would have required reentering data by hand into Version 8 for each mobile home.

The primary changes made in Version 8 were the addition of administrative features that would be useful in running a weatherization program, such as the ability to develop work orders and track the status of jobs. Although there were some technical enhancements made in Version 8, it was felt that the enhancements would not have affected the energy estimates obtained from using Version 7.4.3.3 for these homes. This assumption was confirmed after data for five mobile homes were entered into Version 8 and no appreciable change was found in the pre- and post-weatherization space-heating energy consumptions estimated by the two versions.

Two steps were taken to ensure that MHEA's energy predictions used in Sect. 4 were accurate and were based on the measures that were actually installed in each mobile home:

- After the field data for each mobile home were entered into MHEA by the agency staff or the author, the MHEA data files were reviewed to ensure that the inputs were reasonable, consistent with other data entered for the home, and consistent with other data available from the agencies on the homes (such as blower door readings and results of flue gas analyses documented on paper forms, pictures of the mobile homes, etc.). Discussions were held with agency personnel as needed to clarify and resolve issues.

- The measures actually installed in each mobile home were identified from information provided by the agencies. The author then developed a unique MHEA setup or parameter set for each mobile home so that MHEA would estimate post-weatherization space-heating energy consumptions and energy savings just for the measures actually installed in each mobile home. 
For each mobile home, actual pre- and post-weatherization blower door readings were used in MHEA. Normally, at the time an audit is performed, the auditor must enter an estimated value for the post-weatherization air leakage rate because the infiltration work has not yet been done. For the field validation, actual post-weatherization blower door readings were used because (a) MHEA was rerun after each mobile home was weatherized, and (b) the intent was to validate the accuracy of MHEA's calculations rather than the accuracy that someone can estimate post-weatherization air leakage rates at the time of an audit.

The primary analyses presented in Sect. 4 were based on MHEA runs that did not consider duct leakage (i.e., the "Evaluate duct sealing" check box on the "Ducts \& Infiltration" tab in MHEA was not checked). However, in a subset of mobile homes in which pre- and post-weatherization pressure pan measurements were made by the agencies, a second set of energy estimates were made by rerunning MHEA to consider duct leakage using these measurements to quantify the duct leakage. A comparison of the energy estimates considering and not considering duct leakage is presented in Sect. 4.2.3.

MHEA includes an optional billing adjustment feature that adjusts its annual energy savings estimates of measures based on pre-weatherization billing data (if entered). MHEA analyzes the preweatherization billing data to estimate an annual space-heating heating energy consumption and compares this to its annual pre-weatherization space-heating heating energy consumption estimate, which is based on the characteristics of the mobile home. MHEA decreases its estimated annual space-heating energy savings for all heating-related weatherization measures if the annual spaceheating energy consumption indicated by the billing data is less than MHEA's estimate, and increases its estimated annual space-heating energy savings if the reverse is true. The change is approximately proportional to the ratio between the annual pre-weatherization space-heating energy consumption based on the billing data to that estimated by MHEA. For example, if MHEA estimated an annual pre-weatherization space-heating energy consumption of $100 \mathrm{MBtu}$ and the billing data indicated an annual consumption of $80 \mathrm{MBtu}$, then the ratio is $80 / 100$ or 0.8 , and MHEA would decrease the annual space-heating energy savings of all heating-related measures to about $80 \%$ of their original values (or by about $20 \%$ ).

The primary analyses of space-heating energy savings presented in Sect. 4 were based on MHEA annual energy saving estimates that did not use the billing adjustment feature. This was done in order to investigate the accuracy of MHEA's annual space-heating energy saving estimates before any adjustments occurred, and because billing data are not routinely collected and used by agencies as part of their auditing processes. However, a secondary analysis presented in Sect. 4.2.1 did investigate the impact of using billing data and the billing data adjustment feature to improve accuracy. In performing this analysis, the actual billing data were not entered into MHEA. Rather, estimates of annual pre-weatherization space-heating energy consumption developed from an analysis of the billing data for each mobile home were used (see Sect. 2.3.1). This was done to eliminate any inaccuracies associated with MHEA's simplistic methods for estimating the annual space-heating component of billing data, so that the best performance from using MHEA's billing adjustment feature could be determined. 


\subsection{BILLING ANALYSES}

\subsubsection{Primary Space-Heating Fuel}

The monthly billing/delivery data for the fuel used by the primary space-heating system in each mobile home (natural gas, electricity, or propane) were analyzed using the Princeton Scorekeeping Method (PRISM, Fels et al. 1995) to determine annual space-heating energy consumptions before and after weatherization and annual energy savings normalized to long-term weather conditions.

In its traditional heating-only model, PRISM determines a weather-adjusted annual index of fuel consumption, termed the Normalized Annual Consumption (NAC), for each period (i.e., the preweatherization period and the post-weatherization period) for each mobile home. PRISM also splits the NAC for the fuel being analyzed into two components and calculates values for these: the normalized annual heating consumption (NAHC) and the baseload energy consumption. NAHC represents the part of NAC that fluctuates with changes in outdoor temperature, while the baseload energy consumption represents the part of NAC that stays constant regardless of outdoor temperature variations. For each period, NAHC and baseload energy consumption (and to a lesser extent NAC) are dependent on the heating reference temperature (or balance point temperature) used within PRISM to calculate heating degree days. The heating reference temperature represents the outdoor temperature below which heating fuel is required for a home. PRISM is typically allowed to vary the heating reference temperature in each period until the best statistical model is achieved; the heating reference temperature is then reported along with the other estimators already discussed for each period.

The NAC is the most robust estimator produced by PRISM. Its value is fairly independent of the heating reference temperature, whereas NAHC and the baseload energy consumption are sensitive to the heating reference temperature chosen. Seasonal variability of appliances, lighting, water use, water temperatures, solar gains, and other factors also interfere with the calculations and interpretations of NAHC, "baseload" energy consumption, and even the heating reference temperature, but have relatively little impact on NAC. ${ }^{1}$

Although NAHC is a less robust estimator than NAC, NAHC is the estimator used in the analyses performed in Sect. 4 to establish actual pre- and post-weatherization space-heating energy consumptions and savings. MHEA estimates annual pre- and post-weatherization space-heating energy consumptions rather than annual whole-house fuel use; therefore, NAHC rather than NAC is conceptually equivalent to MHEA's estimates. In mobile homes heated by natural gas or propane, annual space-heating energy savings could be based on differences between pre- and postweatherization NAC values if few baseload measures were installed and/or the annual savings associated with baseload measures was small; however, in mobile homes heated by electricity, differences in NAC would also include savings or changes in energy consumption associated with space cooling. Thus, NAHC rather than NAC is again the best indicator to use for this validation.

In order to ensure an accurate analysis for each mobile home considering that the less robust NAHC indicator was to be used, each mobile home was examined individually and multiple PRISM runs were made for each home before selecting the final pre- and post-weatherization models as outlined below:

\footnotetext{
${ }^{1}$ There is some belief that PRISM tends to overestimate NAHC and underestimate the baseload energy consumption because weather-dependent and/or seasonal baseload energy consumption gets integrated into the weather-dependent NAHC.
} 
- For the mobile homes heated by natural gas or electricity, only the billing data about a year before and a year after weatherization were generally used in the final PRISM runs to make sure the PRISM estimates were based on the same conditions that existed at the time the homes were audited. PRISM was initially run using all the pre- and post-weatherization data available for each home, but in some cases it was evident that the energy consumption of the home was changing with time (e.g., two years before or after weatherization) for unknown reasons. Because MHEA's estimates were based on the conditions and occupancy of the mobile homes at the time they were audited, it was felt that restricting PRISM to billing data a year before and a year after weatherization would make PRISM base its estimates on these same conditions.

- For all the mobile homes regardless of fuel type, the heating reference temperatures for the pre- and post-weatherization periods were manually selected for each home. Allowing PRISM to select the heating reference temperature that resulted in the best statistical model led to mobile homes with (a) very low heating reference temperatures, (b) heating reference temperatures before and after weatherization that were significantly different from one another (even after considering that the heating reference temperature may decrease as a home becomes more energy efficient), (c) baseload energy consumptions that were not consistent with a visual examination of the billing data, (d) large differences in baseload energy consumptions before and after weatherization that could not be justified based on the baseload measures installed in the home (or that even increased significantly), and (e) in the case of mobile homes heated by propane, baseload energy consumptions that were significantly different than zero (and negative in some cases) even though propane was only used for space heating. After identifying the PRISM-selected heating reference temperatures, the temperatures were manually selected to address the problems outlined above as best as possible based on a visual examination of the data.

- Mobile homes heated by propane were successfully modeled in PRISM after iterative runs were made. Unlike monthly natural gas or electricity billing data, propane deliveries can occur just several times a year, do not always represent the consumption for the period (because the tank is not always filled with each delivery), and may have gaps in the data because propane can be bought from multiple distributors. Therefore, to overcome these problems for the mobile homes heated by propane, extra efforts were made during data collection to obtain delivery data for as many years as possible, and all available delivery data were used rather than just the year before and after weatherization as discussed in the first bullet above. In addition, by visually examining the data and using PRISM's checks for finding outliers and estimated readings, individual deliveries could be combined so that the delivery data did reflect consumption. As mentioned in the bullet above, the heating reference temperatures used in PRISM were those that made the baseload energy consumption zero in mobile homes where it was known that propane was used only for space heating. For a few mobile homes, the delivery data were analyzed using a simple heating degree day method to confirm the reasonableness of PRISM's estimates; PRISM's estimates were replaced by the results from the simple heating degree day method in just one home.

- In mobile homes heated by electricity, PRISM's heating-and-cooling model was applied in addition to its heating-only model because the data indicated that many of the homes used electricity for cooling. Multiple PRISM runs were made using both models and various heating and cooling reference temperatures before the best model was selected based on a visual examination of the data and the model results. If PRISM was allowed to select the best model (and best heating and cooling reference temperatures) automatically, the heating-only 
model was usually selected even though an electricity spike in the summer was clearly evident from a visual examination of the data. Inconsistent base load consumptions, models where the space-cooling energy use decreased with increasing cooling degree days, and other abnormalities also occurred if PRISM was allowed to automatically select the model type and heating and cooling reference temperatures based on purely statistical considerations.

The weather period typically used in PRISM to calculate the normalized annual consumptions was also used in this study; namely, the period spanning January 1, 1980 through December 31, 1991. MHEA bases its estimates on a Typical Meteorological Year (typically called TMY weather data) as compiled by the National Oceanic and Atmospheric Administration (NOAA), which represents typical weather conditions as they occurred between 1948 and 1980 (National Climatic Data Center 1981). This older and longer time period was not used in PRISM because the needed data were not available. However, it is doubtful that the findings presented in Sect. 4 were significantly affected because different weather years were used for the normalization.

\subsubsection{Supplemental Space-Heating Electricity Use}

Electricity billing data were collected on many of the mobile homes heated by natural gas or propane and analyzed to determine how much supplemental space-heating electricity use was occurring. These billing data were analyzed in a manner similar to that described in Sect. 2.3.1 for the mobile homes heated by electricity: PRISM's heating-and-cooling and heating-only models were both used, and heating and cooling reference temperatures were manually selected. Results are discussed in Sect. 4.1.3. 


\section{MOBILE HOME AND WEATHERIZATION CHARACTERISTICS}

As discussed in Sect. 2, data were collected and analyzed on 86 mobile homes to validate MHEA's energy saving predictions. The general characteristics of these 86 mobile homes and the weatherization measures installed in them are discussed in this section.

\subsection{MOBILE HOME CHARACTERISTICS}

The general characteristics of the 86 mobile homes used in this study are presented in Table 3.1. Most of the mobile homes were heated primarily by natural gas ( 49 or $57 \%$ ), while about equal numbers were heated primarily by either electricity (18 or $21 \%$ ) or propane (19 or $22 \%)$.

The average floor area of the mobile homes was $939 \mathrm{ft}^{2}$ and did not vary considerably by the type of primary space-heating fuel used. The floor areas ranged in size from $500 \mathrm{ft}^{2}$ up to $1680 \mathrm{ft}^{2}$ for a double-wide unit. About a quarter of the mobile homes heated primarily by natural gas had additions (the floor area of the additions are included in the average floor area values), while only two of the propane-heated homes and none of the electrically heated homes had additions.

On average, the mobile homes had $4.2 \mathrm{in}$. of insulation in the ceiling, $2.0 \mathrm{in}$. in the floor, and $2.8 \mathrm{in}$. in the walls. The homes that used natural gas as the primary space-heating fuel had less insulation, on average, in the ceiling, floor, and walls compared to homes heated by either electricity or propane.

Many of the mobile homes had 1 in. or less of insulation in either the ceiling, floor, or walls. This was especially true for floors, where 38 of the 86 homes (44\%) had 1 in. or less of insulation in the wing or belly areas of the floor. Ceilings had 1 in. or less of insulation in $15 \%$ of the homes, and walls had 1 in. or less of insulation in just 5\% of the homes. A lack of at least 1 in. of insulation occurred most frequently in homes heated primarily by natural gas and propane (with the exception of walls in propane-heated homes). Homes heated primarily by electricity generally had more than 1 in. of insulation in all three envelope areas.

The windows in $36 \%$ of the mobile homes were predominantly single-pane without storm windows. The frequency did not vary considerably by the type of primary space-heating fuel used.

The average pre-weatherization air leakage rate of the mobile homes was $2495 \mathrm{cfm} 50$ and did not vary considerably by the type of primary space-heating fuel used. As shown in Fig. 3.1, about a quarter of the mobile homes were very leaky before weatherization, having an air leakage rate greater than $3000 \mathrm{cfm} 50$, and about $40 \%$ were already fairly tight, having an air leakage rate of less than $2000 \mathrm{cfm} 50$.

\subsection{WEATHERIZATION MEASURES}

As discussed in Sect. 2.1, three states selected weatherization measures to be installed in the validation mobile homes using their current audit methods, and two states used MHEA's recommendations. The frequency that measures were installed is provided in Table 3.2. 
Table 3.1. Characteristics of the mobile homes

\begin{tabular}{|c|c|c|c|c|}
\hline \multirow[b]{2}{*}{ Characteristic } & \multirow{2}{*}{$\begin{array}{l}\text { All mobile } \\
\text { homes }\end{array}$} & \multicolumn{3}{|c|}{ Mobile homes heated by: } \\
\hline & & Electricity & Natural gas & Propane \\
\hline Number & 86 & $18(21 \%)$ & $49(57 \%)$ & $19(22 \%)$ \\
\hline Floor area & $939 \mathrm{ft}^{2}$ & $944 \mathrm{ft}^{2}$ & $928 \mathrm{ft}^{2}$ & $960 \mathrm{ft}^{2}$ \\
\hline Number with additions & $\begin{array}{l}14(16 \% \text { of all } \\
\text { mobile homes })\end{array}$ & $0(0 \%)$ & $\begin{array}{l}12(24 \% \text { of } \\
\text { natural gas } \\
\text { homes, } 86 \% \text { of } \\
\text { homes with } \\
\text { additions }) \\
\end{array}$ & $\begin{array}{l}2(11 \% \text { of } \\
\text { propane homes, } \\
14 \% \text { of homes } \\
\text { with additions })\end{array}$ \\
\hline \multicolumn{5}{|l|}{ Ceiling insulation: } \\
\hline Average depth & 4.2 in. & 4.6 in. & 3.9 in. & 4.6 in. \\
\hline Number with $\leq 1$ in. & $\begin{array}{l}13(15 \% \text { of all } \\
\text { mobile homes })\end{array}$ & $\begin{array}{l}1(6 \% \text { of } \\
\text { electric homes, } \\
8 \% \text { of homes } \\
\text { with } \leq 1 \text { in. of } \\
\text { ceiling } \\
\text { insulation }\end{array}$ & $\begin{array}{l}8 \text { (16\% of natural } \\
\text { gas homes, } 62 \% \\
\text { of homes with } \leq \\
1 \text { in. of ceiling } \\
\text { insulation }\end{array}$ & $\begin{array}{l}4(21 \% \text { of } \\
\text { propane homes, } \\
31 \% \text { of homes } \\
\text { with } \leq 1 \text { in. of } \\
\text { ceiling } \\
\text { insulation }\end{array}$ \\
\hline \multicolumn{5}{|l|}{ Floor insulation: } \\
\hline Average depth (wing) & 2.0 in. & $2.8 \mathrm{in}$. & 1.6 in. & 2.1 in. \\
\hline Average depth (belly) & 2.0 in. & 2.7 in. & 1.6 in. & 2.4 in. \\
\hline Number with $\leq 1$ in. & $\begin{array}{l}38(44 \% \text { of all } \\
\text { mobile homes) }\end{array}$ & $\begin{array}{l}2(11 \% \text { of } \\
\text { electric homes, } \\
5 \% \text { of homes } \\
\text { with } \leq 1 \text { in. of } \\
\text { insulation in } \\
\text { wing or belly }\end{array}$ & $\begin{array}{l}25(51 \% \text { of } \\
\text { natural gas } \\
\text { homes, } 66 \% \text { of } \\
\text { homes with } \leq 1 \\
\text { in. of insulation } \\
\text { in wing or belly }\end{array}$ & $\begin{array}{l}11(58 \% \text { of } \\
\text { propane homes, } \\
29 \% \text { of homes } \\
\text { with } \leq 1 \text { in. of } \\
\text { insulation in } \\
\text { wing or belly }\end{array}$ \\
\hline \multicolumn{5}{|l|}{ Wall insulation: } \\
\hline Average depth & 2.8 in. & $2.7 \mathrm{in}$. & 2.6 in. & 3.2 in. \\
\hline Number with $\leq 1$ in. & $\begin{array}{l}4(5 \% \text { of all } \\
\text { mobile homes) }\end{array}$ & $0(0 \%)$ & $\begin{array}{l}4(8 \% \text { of natural } \\
\text { gas homes, } 100 \% \\
\text { of homes with } \leq \\
1 \text { in. of ceiling } \\
\text { insulation }\end{array}$ & $0(0 \%)$ \\
\hline $\begin{array}{l}\text { Windows - number of } \\
\text { mobile homes with } \\
\text { predominantly single- } \\
\text { pane windows without } \\
\text { storms }\end{array}$ & $\begin{array}{l}31 \text { ( } 36 \% \text { of all } \\
\text { mobile homes) }\end{array}$ & $\begin{array}{l}7(39 \% \text { of } \\
\text { electric homes, } \\
23 \% \text { of homes } \\
\text { with } \\
\text { predominantly } \\
\text { single-pane } \\
\text { windows } \\
\text { without storms }\end{array}$ & $\begin{array}{l}17(35 \% \text { of } \\
\text { natural gas } \\
\text { homes, } 55 \% \text { of } \\
\text { homes with } \\
\text { predominantly } \\
\text { single-pane } \\
\text { windows without } \\
\text { storms }\end{array}$ & $\begin{array}{l}7(37 \% \text { of } \\
\text { propane homes, } \\
23 \% \text { of homes } \\
\text { with } \\
\text { predominantly } \\
\text { single-pane } \\
\text { windows } \\
\text { without storms }\end{array}$ \\
\hline $\begin{array}{l}\text { Pre-weatherization } \\
\text { blower door reading }\end{array}$ & $2495 \mathrm{cfm} 50$ & $2560 \mathrm{cfm} 50$ & $2478 \mathrm{cfm} 50$ & $2475 \mathrm{cfm} 50$ \\
\hline
\end{tabular}




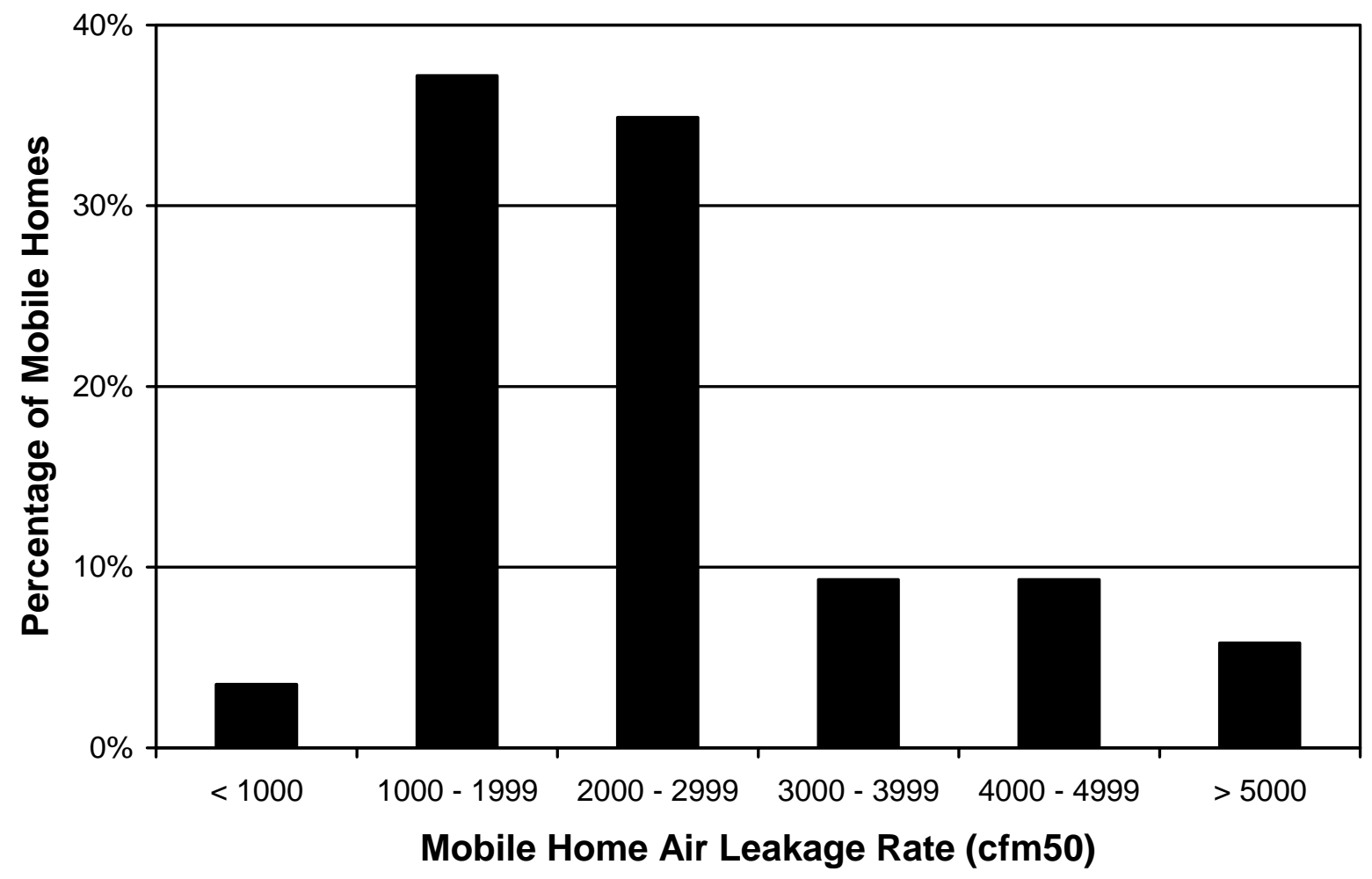

Figure 3.1. Distribution of pre-weatherization air leakage rates.

Floor insulation was performed in a majority of the homes $(87 \%)$ and was installed more frequently than ceiling insulation (52\%) and wall insulation (10\%). This is consistent with the characteristics of the homes described in Sect.3.1 (i.e., that the floors more frequently had 1 in. or less of insulation than ceilings and walls, and the average wall insulation thickness of $2.8 \mathrm{in}$. indicated that most wall cavities were already fully insulated). This is also consistent with the design of the participating state programs, the measures that these states allow and encourage their agencies to perform, and the measures that the agencies have been trained to perform. Insulation was more frequently installed in the homes heated primarily by natural gas, which is consistent with the lower levels of insulation observed in these homes compared to homes heated primarily by electricity or propane (see Sect. 3.1).

As expected, air and duct sealing were performed in almost all the validation homes. Half of the homes received a new door(s), and at least one window (likely more) was replaced or received a storm window in slightly less than half of the homes (consistent with the fact that about a third of the homes had predominantly single-pane windows without storm windows as described in Sect. 3.1).

A new heating system, a heating-system tune-up, and a setback thermostat were installed in $21 \%$, $20 \%$, and $19 \%$ of the mobile homes, respectively. These were installed predominantly in homes heated primarily by natural gas or propane (the heating system in one electric home was replaced), although repairs were made to heating systems in several electrically heated homes. 
Table 3.2. Installation frequency of weatherization measures

\begin{tabular}{|c|c|c|c|c|}
\hline \multirow[b]{2}{*}{ Measure } & \multirow{2}{*}{$\begin{array}{c}\text { All mobile } \\
\text { homes } \\
\text { (86 homes) }\end{array}$} & \multicolumn{3}{|c|}{ Mobile homes heated by: } \\
\hline & & $\begin{array}{l}\text { Electricity } \\
\text { (18 homes) }\end{array}$ & $\begin{array}{c}\text { Natural gas } \\
\text { (49 homes) }\end{array}$ & $\begin{array}{c}\text { Propane } \\
\text { (19 homes) }\end{array}$ \\
\hline Air and duct sealing & $95 \%$ & $100 \%$ & $96 \%$ & $89 \%$ \\
\hline \multicolumn{5}{|l|}{ Envelope measures: } \\
\hline Ceiling insulation & $52 \%$ & $33 \%$ & $59 \%$ & $53 \%$ \\
\hline Floor insulation & $87 \%$ & $78 \%$ & $92 \%$ & $84 \%$ \\
\hline Wall insulation & $10 \%$ & $6 \%$ & $14 \%$ & $5 \%$ \\
\hline Window treatment ${ }^{*}$ & $43 \%$ & $33 \%$ & $41 \%$ & $58 \%$ \\
\hline New exterior door(s) & $50 \%$ & $67 \%$ & $39 \%$ & $63 \%$ \\
\hline \multicolumn{5}{|l|}{ Space-heating system measures: } \\
\hline New heating system & $21 \%$ & $6 \%$ & $29 \%$ & $16 \%$ \\
\hline Heating system tune-up & $20 \%$ & $0 \%$ & $24 \%$ & $26 \%$ \\
\hline Setback thermostat & $19 \%$ & $0 \%$ & $16 \%$ & $26 \%$ \\
\hline Heating system repair & $6 \%$ & $11 \%$ & $6 \%$ & $0 \%$ \\
\hline \multicolumn{5}{|l|}{ Space-cooling system measures: } \\
\hline New air conditioning system & $1 \%$ & $0 \%$ & $2 \%$ & $0 \%$ \\
\hline Air-conditioner tune-up & $2 \%$ & $6 \%$ & $0 \%$ & $5 \%$ \\
\hline \multicolumn{5}{|l|}{ Water-heating system measures: } \\
\hline New water heater & $14 \%$ & $17 \%$ & $18 \%$ & $0 \%$ \\
\hline Water heater tank insulation & $21 \%$ & $39 \%$ & $20 \%$ & $5 \%$ \\
\hline Water heater pipe insulation & $40 \%$ & $56 \%$ & $37 \%$ & $32 \%$ \\
\hline Low-flow shower head & $7 \%$ & $0 \%$ & $6 \%$ & $16 \%$ \\
\hline Faucet aerator & $24 \%$ & $0 \%$ & $31 \%$ & $32 \%$ \\
\hline \multicolumn{5}{|l|}{ Other baseload measures: } \\
\hline Refrigerator & $14 \%$ & $0 \%$ & $18 \%$ & $16 \%$ \\
\hline Lighting & $34 \%$ & $6 \%$ & $45 \%$ & $32 \%$ \\
\hline
\end{tabular}

One or more windows was replaced or received a storm window

Remaining measures installed in the mobile homes primarily dealt with baseload energy use: water heating, refrigerators, and lighting. However, three homes did receive measures that impacted airconditioning electricity use: one home received a new air conditioning system and the existing air conditioner was tuned in two homes. 


\section{RESULTS}

As discussed in Sect. 2.1, data were collected and analyzed on 86 mobile homes to validate MHEA's annual space-heating energy saving predictions and MHEA's estimates of the amount of insulation needed to insulate mobile home floors, attics, and walls. Results of these analyses are presented in this section.

\subsection{ANNUAL SPACE-HEATING ENERGY CONSUMPTIONS AND SAVINGS}

\subsubsection{Accuracy Expectations and Limitations}

Before presenting the actual validation results of MHEA's energy saving predictions, it is important to understand the impact inaccuracies in estimating annual pre- and post-weatherization space-heating energy consumptions can have in estimating annual energy savings and the resulting energy savings realization rate (i.e., the amount of energy savings realized compared to predicted, equal to the actual savings divided by the predicted savings and expressed as a percentage).

As shown in Table 4.1, assume that the annual pre-weatherization space-heating energy consumption of a home is 80 units of energy and that following weatherization the annual energy consumption is 60 units of energy, such that the actual annual savings is 20 units or $25 \%$. If a prediction tool overpredicts or underpredicts the pre-weatherization energy consumption by just $10 \%$ while accurately predicting the post-weatherization consumption, the resulting realization rates are $71 \%$ and $167 \%$, respectively. Similarly, if the prediction tool accurately predicts the pre-weatherization consumption but overpredicts or underpredicts the post-weatherization energy consumption by just $10 \%$, then the resulting realization rates are $143 \%$ and $77 \%$, respectively. If the prediction tool overpredicts and underpredicts both the pre- and post-weatherization energy consumptions by $10 \%$, then realization rates can vary from $59 \%$ to $333 \%$ depending on the various possible combinations. In fact, to achieve realization rates between $75 \%$ and $150 \%$, the pre-weatherization energy consumption cannot be overpredicted or underpredicted by more than $8.3 \%$, the post-weatherization energy consumption cannot be overpredicted or underpredicted by more than $11.2 \%$, or under the worse case conditions where the pre-weatherization energy consumption is overpredicted and the postweatherization energy consumption is underpredicted (or vice-versa), then the prediction tool must be accurate to within $4.8 \%$ of actual consumption. If the actual savings is just 10 units of energy $(12.5 \%)$, then the realization rates are much lower and higher than those discussed assuming a 25\% savings, and the prediction tool would have to be accurate to within $2.2 \%$ or better under worst-case conditions to achieve realization rates between $75 \%$ to $150 \%$.

MHEA is an energy audit tool designed to be easily used by trained weatherization crew personnel who are knowledgeable about mobile homes, energy systems, and weatherization but who are not energy engineers or scientists. MHEA is not designed to be as detailed, nor is it expected to be as accurate, as energy simulation tools such as BLAST, DOE-2, or EnergyPlus. However, it is not uncommon for these sophisticated tools to predict annual space-heating energy consumptions that differ by about $5 \mathrm{MBtu}$ out of 65 to $85 \mathrm{MBTU}(7.7 \%$ to $5.9 \%)$ when two are applied to the same home (Judkoff and Neymark 1995). Thus, expectations for MHEA to achieve realization rates between $75 \%$ to $150 \%$ (requiring accuracies as low as $4.8 \%$ or even $2.2 \%$ depending on expected savings) may be unrealistic. 
Table 4.1. Impact of energy consumption uncertainties on potential realization rates

\begin{tabular}{|c|c|c|c|c|c|c|}
\hline & \multicolumn{2}{|c|}{$\begin{array}{l}\text { Annual pre- } \\
\text { weatherization space- } \\
\text { heating energy } \\
\text { consumption }\end{array}$} & \multicolumn{2}{|c|}{$\begin{array}{c}\text { Annual post- } \\
\text { weatherization space- } \\
\text { heating energy } \\
\text { consumption }\end{array}$} & \multirow{2}{*}{$\begin{array}{c}\begin{array}{c}\text { Annual } \\
\text { energy } \\
\text { savings }\end{array} \\
\begin{array}{c}\text { Energy } \\
\text { units }\end{array} \\
\end{array}$} & \multirow{2}{*}{$\begin{array}{c}\begin{array}{c}\text { Realization } \\
\text { rate }\end{array} \\
\%\end{array}$} \\
\hline & $\begin{array}{c}\text { Energy } \\
\text { units }\end{array}$ & $\begin{array}{c}\text { \% off from } \\
\text { actual }\end{array}$ & $\begin{array}{c}\text { Energy } \\
\text { units }\end{array}$ & $\begin{array}{c}\text { \% off from } \\
\text { actual }\end{array}$ & & \\
\hline \multicolumn{7}{|c|}{ ACTUAL SAVINGS IS 25\% } \\
\hline Actual & 80 & & 60 & & 20 & \\
\hline \multicolumn{7}{|c|}{ If prediction of pre-weatherization energy consumption is off $10 \%$ : } \\
\hline & 88 & $10 \%$ & 60 & $0 \%$ & 28 & $71 \%$ \\
\hline & 72 & $-10 \%$ & 60 & $0 \%$ & 12 & $167 \%$ \\
\hline \multicolumn{7}{|c|}{ If prediction of post-weatherization energy consumption is off $10 \%$ : } \\
\hline & 80 & $0 \%$ & 66 & $10 \%$ & 14 & $143 \%$ \\
\hline & 80 & $0 \%$ & 54 & $-10 \%$ & 26 & $77 \%$ \\
\hline \multicolumn{7}{|c|}{ If prediction of pre- and post-weatherization energy consumptions are both off $10 \%$ : } \\
\hline & 88 & $10 \%$ & 66 & $10 \%$ & 22 & $91 \%$ \\
\hline & 72 & $-10 \%$ & 54 & $-10 \%$ & 18 & $111 \%$ \\
\hline & 88 & $10 \%$ & 54 & $-10 \%$ & 34 & $59 \%$ \\
\hline & 72 & $-10 \%$ & 66 & $10 \%$ & 6 & $333 \%$ \\
\hline \multicolumn{7}{|c|}{ Values needed to achieve a $75 \%$ or $150 \%$ realization rate: } \\
\hline & 86.6 & $8.3 \%$ & 60 & $0 \%$ & 26.6 & $75 \%$ \\
\hline & 80.0 & $0 \%$ & 53.3 & $-11.2 \%$ & 26.7 & $75 \%$ \\
\hline & 83.8 & $4.8 \%$ & 57.1 & $-4.8 \%$ & 26.7 & $75 \%$ \\
\hline & 73.4 & $-8.3 \%$ & 60 & $0 \%$ & 13.4 & $150 \%$ \\
\hline & 80 & $0 \%$ & 66.7 & $11.2 \%$ & 13.3 & $150 \%$ \\
\hline & 76.2 & $-4.8 \%$ & 62.9 & $4.8 \%$ & 13.3 & $150 \%$ \\
\hline \multicolumn{7}{|c|}{ ACTUAL SAVINGS IS 12.5\% } \\
\hline Actual & 80 & & 70 & & 10 & \\
\hline \multicolumn{7}{|c|}{ If prediction of pre-weatherization energy consumption is off $10 \%$ : } \\
\hline & 88 & $10 \%$ & 70 & $0 \%$ & 18 & $56 \%$ \\
\hline & 72 & $-10 \%$ & 70 & $0 \%$ & 2 & $500 \%$ \\
\hline \multicolumn{7}{|c|}{ If prediction of post-weatherization energy consumption is off $10 \%$ : } \\
\hline & 80 & $0 \%$ & 77 & $10 \%$ & 3 & $333 \%$ \\
\hline & 80 & $0 \%$ & 63 & $-10 \%$ & 17 & $59 \%$ \\
\hline \multicolumn{7}{|c|}{ If prediction of pre- and post-weatherization energy consumptions are both off $10 \%$ : } \\
\hline & 88 & $10 \%$ & 77 & $10 \%$ & 11 & $91 \%$ \\
\hline & 72 & $-10 \%$ & 63 & $-10 \%$ & 9 & $111 \%$ \\
\hline & 88 & $10 \%$ & 63 & $-10 \%$ & 25 & $40 \%$ \\
\hline & 72 & $-10 \%$ & 77 & $10 \%$ & -5 & $-200 \%$ \\
\hline \multicolumn{7}{|c|}{ Values needed to achieve a $75 \%$ or $150 \%$ realization rate: } \\
\hline & 83.3 & $4.1 \%$ & 70 & $0 \%$ & 13.3 & $75 \%$ \\
\hline & 80.0 & $0 \%$ & 66.7 & $-4.7 \%$ & 13.3 & $75 \%$ \\
\hline & 81.8 & $2.2 \%$ & 68.5 & $-2.2 \%$ & 13.3 & $75 \%$ \\
\hline & 76.7 & $-4.1 \%$ & 70 & $0 \%$ & 6.7 & $150 \%$ \\
\hline & 80 & $0 \%$ & 73.3 & $4.7 \%$ & 6.7 & $150 \%$ \\
\hline & 78.2 & $-2.2 \%$ & 71.5 & $2.2 \%$ & 6.7 & $150 \%$ \\
\hline
\end{tabular}




\subsubsection{Analyses Using All Homes}

Based on an analysis of the primary space-heating fuel data for all 86 homes (see Table 4.2), MHEA overpredicted annual pre-weatherization space-heating energy consumption by $33 \%$ but predicted the annual post-weatherization space-heating energy consumption fairly accurately (underprediction of $1.5 \%$ ). As a result, MHEA overestimated the annual space-heating energy savings by $195.8 \%$ and achieved an average realization rate of just $33.8 \%$. Because post-weatherization billing data could not be collected and/or analyzed for 14 of the 86 mobile homes with pre-weatherization billing data, postweatherization and savings results are based on 72 mobile homes.

Although not a principal purpose of the evaluation, the average annual space-heating energy savings that was measured in the mobile homes, $13.8 \mathrm{MBtu}$, was about $20 \%$ of the average annual preweatherization space-heating energy consumption of the homes. This is higher than the $9 \mathrm{MBtu}$ (11.4\%) savings measured recently in mobile homes weatherized in Ohio (Khawaja et al. 2006) and the $12 \mathrm{MBtu}(12 \%)$ savings measured in mobile homes weatherized nationally in 1979 (Brown et al. 1993). Figure 4.1 shows how the measured savings varied as a function of the actual preweatherization space-heating energy consumption. The figure shows that the annual savings for individual mobile homes ranged from about -10 MBtu/year to about $50 \mathrm{MBtu} / \mathrm{year}$ (when comparing the magnitude of the energy consumptions and savings of the homes heated primarily by electricity to the natural gas and propane homes, bear in mind that the electricity data were converted from $\mathrm{kWh}$ to MBtu for homes heated by electricity). The figure also shows that measured savings were negative in 11 mobile homes despite the fact that weatherization measures were installed in these homes (although most of the natural gas and propane homes with negative savings were those with low preweatherization energy consumptions). It should be noted that measuring a negative savings in some homes occurs in most energy studies, especially those using billing data as the primary energy data. For the validation of MHEA, the importance of these savings is to indicate that high-impact weatherization measures were installed in the mobile homes used in this study, and that these measures produced appreciable energy space-heating savings that could be estimated by MHEA (i.e., the validation was not performed using measures that produced small savings that would have been difficult to estimate).

Mobile homes heated by the three primary space-heating fuels (electricity, natural gas, and propane) followed the same general pattern as for all the homes combined such that annual space-heating energy savings were overpredicted by $113.1 \%$ to $215.6 \%$ and realization rates ranged from $31.7 \%$ to $46.9 \%$. Several major fuel-specific differences were observed:

- Mobile homes heated by propane behaved somewhat differently than homes heated by natural gas despite the similarity between the two heating systems: MHEA's overprediction of annual pre-weatherization space-heating energy consumption was much less for the propane heated homes (12.7\%) compared to the natural gas homes $(43.5 \%)$, and MHEA underpredicted the annual post-weatherization space-heating energy consumption of the propane-heated homes by $22 \%$ while only slightly overpredicting the consumption for the natural gas homes $(4.4 \%)$. Similar realization rates occurred for both fuels because the relative difference in the accuracy of MHEA's predictions of annual pre- and postweatherization space-heating energy consumptions remained about the same for both fuels. 
Table 4.2. Comparison of MHEA estimates to actual space-heating energy consumptions and savings

\begin{tabular}{|c|c|c|c|c|c|c|c|c|c|c|c|c|c|}
\hline \multirow[b]{2}{*}{$\begin{array}{l}\text { Group of } \\
\text { homes }\end{array}$} & \multicolumn{4}{|c|}{$\begin{array}{c}\text { Annual pre-weatherization space- } \\
\text { heating energy consumption (MBtu) }\end{array}$} & \multicolumn{4}{|c|}{$\begin{array}{c}\text { Annual post-weatherization space- } \\
\text { heating energy consumption (MBtu) }\end{array}$} & \multicolumn{5}{|c|}{ Annual space-heating energy savings (MBtu) } \\
\hline & MHEA & Actual & $\begin{array}{c}\text { MHEA } \\
\text { over- } \\
\text { prediction }\end{array}$ & $\begin{array}{l}\text { No. of } \\
\text { homes }\end{array}$ & MHEA & Actual & $\begin{array}{c}\text { MHEA } \\
\text { over- } \\
\text { prediction }\end{array}$ & $\begin{array}{l}\text { No. of } \\
\text { homes }\end{array}$ & MHEA & Actual & $\begin{array}{c}\text { MHEA } \\
\text { over- } \\
\text { prediction }\end{array}$ & $\begin{array}{c}\text { Realization } \\
\text { rate }\end{array}$ & $\begin{array}{l}\text { No. of } \\
\text { homes }\end{array}$ \\
\hline \multicolumn{14}{|c|}{ All Mobile Homes — Primary Space-Heating Fuel Only } \\
\hline All fuels & 90.1 & 67.7 & $33.0 \%$ & 86 & 52.4 & 53.2 & $-1.5 \%$ & 72 & 40.9 & 13.8 & $195.8 \%$ & $33.8 \%$ & 72 \\
\hline Electricity $^{*}$ & 46.6 & 40.3 & $15.6 \%$ & 18 & 31.0 & 28.6 & $8.2 \%$ & 15 & 12.6 & 5.9 & $113.1 \%$ & $46.9 \%$ & 15 \\
\hline Natural gas & 110.4 & 77.0 & $43.5 \%$ & 49 & 61.7 & 59.1 & $4.4 \%$ & 42 & 53.2 & 16.9 & $215.6 \%$ & $31.7 \%$ & 42 \\
\hline Propane & 78.6 & 69.8 & $12.7 \%$ & 19 & 47.8 & 61.3 & $-22.0 \%$ & 15 & 34.7 & 13.2 & $162.1 \%$ & $38.2 \%$ & 15 \\
\hline $\begin{array}{l}\text { Two or } \\
\text { more } \\
\text { energy } \\
\text { problems }\end{array}$ & 114.9 & 74.1 & $55.1 \%$ & 31 & 62.4 & 60.2 & $3.7 \%$ & 25 & 62.9 & 17.1 & $267.3 \%$ & $27.2 \%$ & 25 \\
\hline $\begin{array}{l}\text { Only one } \\
\text { or no } \\
\text { energy } \\
\text { problems }\end{array}$ & 76.1 & 64.1 & $18.7 \%$ & 55 & 47.1 & 49.5 & $-4.9 \%$ & 47 & 29.2 & 12.1 & $141.8 \%$ & $41.4 \%$ & 47 \\
\hline \multicolumn{14}{|c|}{ Mobile Homes With Quality Pre- And Post-Weatherization Actual Data - Primary Space-Heating Fuel And Supplemental Space-Heating Electricity" } \\
\hline All fuels & 89.5 & 67.5 & $32.6 \%$ & 43 & 49.6 & 53.5 & $-7.4 \%$ & 43 & 39.9 & 14.0 & $185.9 \%$ & $35 \%$ & 43 \\
\hline Electricity $^{*}$ & 43.1 & 32.9 & $31.3 \%$ & 14 & 30.6 & 27.4 & $11.5 \%$ & 14 & 12.6 & 5.4 & $131.3 \%$ & $43.2 \%$ & 14 \\
\hline Natural gas & 120.3 & 83.4 & $44.2 \%$ & 23 & 60.2 & 64.0 & $-5.9 \%$ & 23 & 60.1 & 19.4 & $209.0 \%$ & $32.4 \%$ & 23 \\
\hline Propane & 79.6 & 87.3 & $-8.8 \%$ & 6 & 53.0 & 74.4 & $-28.8 \%$ & 6 & 26.6 & 12.9 & $106.3 \%$ & $48.5 \%$ & 6 \\
\hline $\begin{array}{l}\text { Two or } \\
\text { more } \\
\text { energy } \\
\text { problems }\end{array}$ & 134.8 & 82.4 & $63.6 \%$ & 11 & 62.2 & 65.3 & $-4.8 \%$ & 11 & 72.6 & 17.1 & $325.0 \%$ & $23.5 \%$ & 11 \\
\hline $\begin{array}{l}\text { Only one } \\
\text { or no } \\
\text { energy } \\
\text { problems }\end{array}$ & 74.0 & 62.4 & $18.5 \%$ & 32 & 45.2 & 49.5 & $-8.6 \%$ & 32 & 28.7 & 12.9 & $122.6 \%$ & $44.9 \%$ & 32 \\
\hline
\end{tabular}

*Eectricity use converted from $\mathrm{kWh}$ to MBtu by multiplying by $0.003413 \mathrm{MBtu} / \mathrm{kWh}$. 


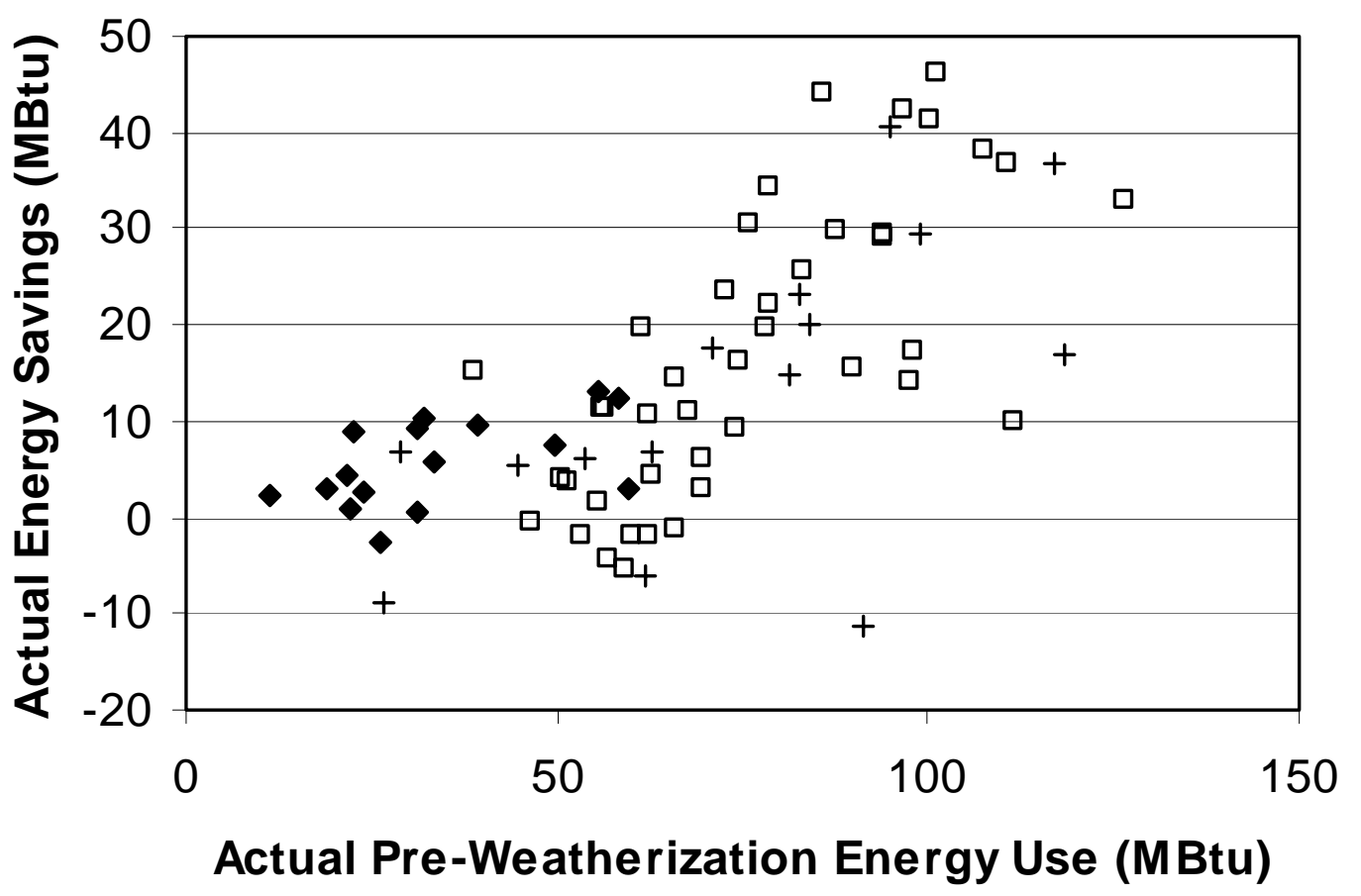

\begin{tabular}{lll}
\hline Electric Natural Gas + Propane \\
\hline
\end{tabular}

Figure 4.1. Annual space-heating energy savings as a function of annual pre-weatherization space-heating energy consumption, both based on the primary space-heating fuel only, for all homes.

- MHEA was more consistent in how well it predicted the annual pre- and post-weatherization space-heating energy consumptions of the electric homes. MHEA overpredicted the preweatherization consumption by $15.6 \%$ and overpredicted the post-weatherization consumption by just $8.2 \%$. Although this resulted in a higher realization rate for the electric homes $(46.9 \%)$ than the homes heated primarily by natural gas or propane $(31.7 \%$ or $38.2 \%$, respectively), the realization rate was still under $50 \%$.

- The annual space-heating energy savings of 5.9 MBtu achieved in the electric homes $(15 \%$ of pre-weatherization consumption ) was less than that saved in the homes heated by natural gas and propane (16.9 MBtu or 22\%, and 13.2 MBtu or 19\%, respectively). However, this is consistent with the results presented in Sect. 3; namely, that the initial insulation levels in the natural gas homes were less than in the electric homes, and fewer insulation and spaceheating system measures were installed in the electric homes compared to the natural gas and propane homes.

Figure 4.2 compares MHEA's estimates of annual pre- and post-weatherization space-heating energy consumptions and energy savings to measured values. MHEA's overestimation of pre-weatherization consumption is evident from Fig. 4.2(a). The overestimation occurs for the majority of homes and occurs across the full range of pre-weatherization energy consumptions. The dashed line in the figure was drawn arbitrarily to identify 14 mobile homes in which the overestimation was most significant. 


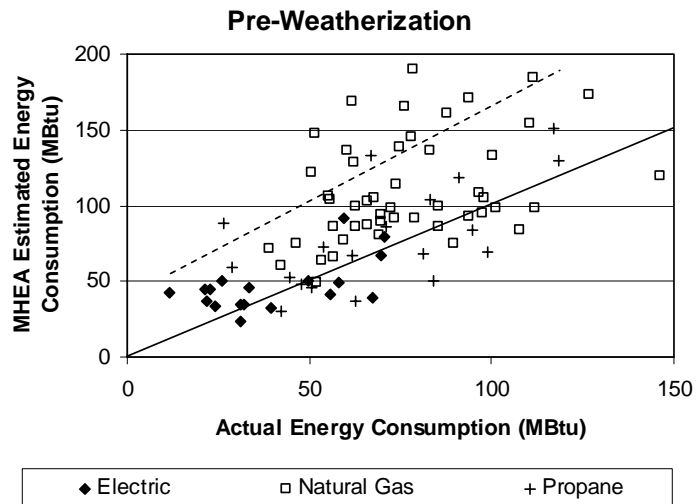

(a)

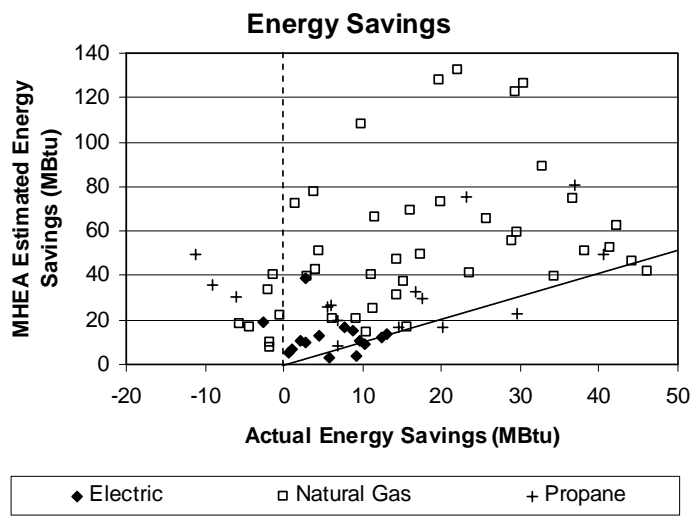

(c)

Figure 4.2. Comparisons of MHEA's annual space-heating energy consumption and savings estimates to actual values (based on the primary space-heating fuel only) using all homes. The solid lines are the lines of agreement between estimated and actual values.

MHEA estimated the average annual post-weatherization space-heating energy consumption quite closely (an average underestimation of just 1.5\%). This is confirmed in Figure 4.2(b), as the data points are scattered equally above and below the line of agreement between predicted and actual values and are reasonably close to the line of equality across the full range of post-weatherization energy consumptions. The dashed line in this figure was again drawn arbitrarily to identify five mobile homes for which MHEA's overestimation was significant. Not unexpectedly, 4 of these were 4 of the 14 homes identified in Fig. 4.2(a) as having significantly high overpredictions of annual preweatherization space-heating energy consumption.

Figure 4.2(c) shows that MHEA overpredicted the annual space-heating energy savings on almost all the mobile homes. Even though Figs. 4.2(a) and (b) show significant scatter in performance of MHEA in individual mobile homes, there must be sufficient consistency within a home that an overprediction of annual space-heating energy savings occurs almost all the time. 


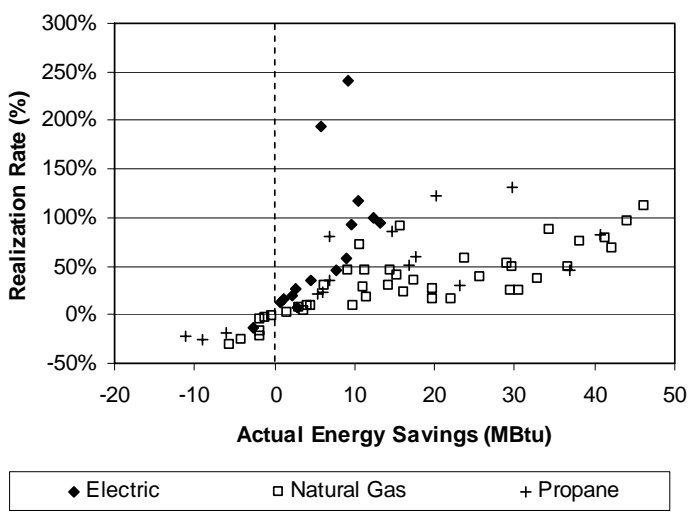

(a)

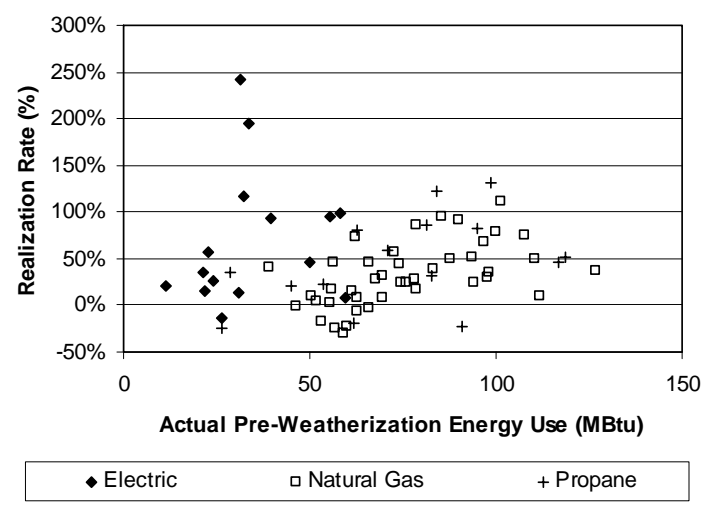

(b)

Figure 4.3. Realization rate as a function of actual annual space-heating energy savings and actual annual pre-weatherization space-heating energy consumption (based on the primary space-heating fuel only) using all homes.

Most of the realization rates for individual mobile homes were between $0 \%$ and $100 \%$, with the heaviest concentration in the $0 \%$ to $50 \%$ range (see Fig. 4.3 ). The realization rate does not appear to be dependent on the actual space-heating energy savings or actual pre-weatherization space-heating energy consumption of the homes. Homes with negative measured savings had negative realization rates. The realization rate for two electrically heated homes were very high (194.5\% and $241.5 \%)$ because (a) MHEA predicted a very low annual space-heating energy savings for them (3.0 and 3.8 MBtu), and (b) even though the measured savings in the homes were small (5.8 and 9.2 MBtu) and within 2.8 and 5.4 MBtu of MHEA's estimates, they were still about twice that predicted by MHEA.

Based upon the results presented thus far in this section, a primary reason for MHEA's overprediction of annual space-heating energy savings and low realization rates is that the annual pre-weatherization space-heating energy consumption is consistently being overestimated. The 14 mobile homes that had significantly high overpredictions of pre-weatherization space-heating energy consumption (those above the dashed line in Figure 4.2 (a)) were investigated to try to determine the reason for this overprediction. This examination revealed that all but 2 of these 14 homes had two or more major efficiency problems defined as a home having:

- 1 in. or less of insulation in the ceiling of the mobile home structure,

- 1 in. or less of insulation in the floor of the mobile home structure,

- 1 in. or less of insulation in the wall of the mobile home structure,

- 1 in. or less of insulation in any envelope area (ceiling, floor, or wall) of an addition,

- A majority of single-pane windows without storms,

- An air leakage rate greater than $3000 \mathrm{cfm} 50$, or

- A space-heating steady-state efficiency of less than $70 \%$.

Applying these criteria to all 86 mobile homes revealed that 31 had two or more major efficiency problems (2.8 problems per home on average) and the other 55 had one or no major problems $(0.5$ problems per home on average). MHEA overpredicted the annual pre-weatherization space-heating energy consumptions of the group of homes with two or more major efficiency problems by $55.1 \%$ on average (see Table 4.2), while the overprediction was only $18.7 \%$ for the group of homes with one or no major efficiency problems. Because MHEA predicted the annual post-weatherization spaceheating energy consumptions of both groups fairly accurately (an overprediction of $3.7 \%$ for one 
group and an underprediction of $4.9 \%$ for the other), the average realization rate for the homes with one of no major efficiency problems $(41.4 \%)$ was significantly higher than that for the group of homes with two or more problems (27.2\%). Thus, it appears that MHEA tends to overpredict annual pre-weatherization space-heating energy consumption in general, which contributes to low realization rates, and overpredicts homes with two or more major efficiency problems in particular.

\subsubsection{Analyses Using a Refined Dataset}

The analyses presented in Sect. 4.1.2 were based on using all the homes and in limiting space-heating energy consumption to the primary space-heating fuel. A refined dataset was created by limiting the dataset to homes with both of the following characteristics:

- Homes in which PRISM's analysis results of the pre- and post-weatherization primary spaceheating fuel data passed selected reliability criteria. PRISM's standard reliability criteria were used when analyzing electricity and natural gas billing data. Homes were dropped from the refined dataset if the $\mathrm{R}^{2}$ was less than 0.7 or the coefficient of variation of the NAC $[\mathrm{CV}(\mathrm{NAC})]$ was greater than $0.07(7 \%)$ for either the pre- or post-weatherization analyses. The reliability criteria for $\mathrm{CV}(\mathrm{NAC})$ was relaxed to $0.16(16 \%)$ for the analyses of propane data to ensure that a minimum number of such mobile homes remained. Using these criteria, 57 mobile homes remained in the dataset: 14 electric, 35 natural gas, and 8 propane.

- Electric homes and homes heated primarily by natural gas or propane that had electric billing data collected on them so that supplemental electric space-heating consumption could be determined and added to the space-heating consumption of the primary space-heating fuel. Although other supplemental space-heating fuels could also have been used in these homes, supplemental electricity consumption was focused on because supplemental electric spaceheating systems are commonly used in mobile homes and electricity billing data were readily available. Refinement of the dataset as described further reduced the total number of homes to 43 , exactly half of the initial dataset: 14 electric, 23 natural gas, and 6 propane.

As shown in Table 4.2, the average performance of MHEA in the homes in the refined dataset differed little from its average performance when applied to all the homes. MHEA's underprediction of annual post-weatherization space-heating energy consumption was slightly higher in the refined dataset than for all the homes (7.4\% compared to $1.5 \%)$, but its overprediction of pre-weatherization energy consumption and energy savings and its low realization rate were about the same.

Some changes did occur between the refined and complete datasets when MHEA's ability to predict annual pre- and post-weatherization space-heating energy consumptions were compared by fuel type, but the bottom line remained the same: realization rates in both datasets ranged from about $30 \%$ to $50 \%$ for the three fuel types. MHEA's overprediction of pre-weatherization space-heating energy consumption increased from $15.6 \%$ to $31.3 \%$ when the number of electric homes was reduced from 18 to 14 in the refined dataset. For the propane homes, MHEA overpredicted pre-weatherization space-heating energy consumption by $12.7 \%$ when all propane homes were used, but underpredicted the consumption by $8.8 \%$ when the refined dataset was used (but note that there are only 6 propane homes in the refined dataset, so the uncertainty associated with this latter average is likely high).

In the refined dataset, 11 homes had two or more major efficiency problems while the remaining 32 homes had just one or no major problems. Analyses of these two groups of homes revealed the same result found when all the homes were used; namely, that MHEA's overprediction of annual preweatherization space-heating energy consumption is much greater in the homes with two or more 
major energy problems than those with just one or none, and the average realization rate for the homes with one or no major efficiency problem is about twice that for the homes with two or more major efficiency problems.

In summary, analyses using the refined dataset produced results that were similar to results when all the homes were used. Thus, MHEA's performance as indicated by the results from all the homes was not generally influenced by inaccurate PRISM results or the use of supplemental electric spaceheating.

\subsubsection{Comparison with Previous Validations}

As mentioned in Sect. 1, there have been two previous validation studies of NEAT (an audit program similar to MHEA) that the results from this validation can be compared to:

- Dalhoff - Dalhoff analyzed data on 408 homes in Iowa whose PRISM results passed selected screens (there were 861 homes in the original dataset). In these homes, $71 \%$ received ceiling insulation, $47 \%$ received wall insulation, and $21 \%$ received a new furnace. The average preweatherization air leakage rate was $3313 \mathrm{cfm} 50$. A refined dataset of 42 homes was developed by only selecting homes that were well-matched on recommended and installed measures, eliminating homes that used default values for the efficiency of the existing furnace, and dropping homes with air leakage rates entered into NEAT that were not reasonably close to values in a secondary tracking system.

- Gettings - Gettings analyzed data on 49 homes in New York. Two refined datasets were developed based on the quality of the PRISM results and quality of the data input into NEAT: one dataset of 12 homes with high quality data, and a second dataset of 31 homes with high and medium quality data.

Table 4.3. Comparison of results to other studies

\begin{tabular}{|c|c|c|c|}
\hline Dataset & $\begin{array}{c}\text { Current MHEA } \\
\text { validation }\end{array}$ & $\begin{array}{c}\text { Dalhoff - NEAT } \\
\text { (Iowa) }\end{array}$ & $\begin{array}{c}\text { Gettings - NEAT } \\
\text { (New York) }\end{array}$ \\
\hline \multicolumn{4}{|c|}{ Annual pre-weatherization space-heating energy consumption: } \\
\hline All homes & Overpredicts by $33.0 \%$ & Overpredicts by $34 \%$ & Overpredicts by $17 \%$ \\
\hline Refined dataset & Overpredicts by $32.6 \%$ & Overpredicts by $8 \%$ & Not available \\
\hline \multicolumn{4}{|c|}{ Annual post-weatherization space-heating energy consumption: } \\
\hline All homes & Underpredicts by $1.5 \%$ & Not available & Underpredicts by $13 \%$ \\
\hline Refined dataset & Underpredicts by $7.4 \%$ & Underpredicts by $11 \%$ & Not available \\
\hline \multicolumn{4}{|c|}{ Annual space-heating energy savings: } \\
\hline All homes & Overpredicts by $195.8 \%$ & Overpredicts by $253.5 \%$ & Overpredicts by $228 \%$ \\
\hline Refined dataset & Overpredicts by $185.9 \%$ & Overpredicts by $183.7 \%$ & Not available \\
\hline \multicolumn{4}{|l|}{ Realization rate: } \\
\hline All homes & $33.8 \%$ & $39 \%$ & $59 \%$ \\
\hline Refined dataset & $35.0 \%$ & $54 \%$ & $51 \%$ and $58 \%$ \\
\hline
\end{tabular}


Table 4.4. Results for the refined dataset with and without billing adjustment

\begin{tabular}{|c|c|c|c|c|c|c|c|}
\hline \multirow{4}{*}{$\begin{array}{c}\text { Homes from } \\
\text { the refined } \\
\text { dataset }\end{array}$} & \multicolumn{5}{|c|}{ Annual space-heating energy savings } & \multicolumn{2}{|c|}{ Realization rate } \\
\hline & & \multicolumn{2}{|c|}{$\begin{array}{l}\text { Without billing } \\
\text { adjustment" }\end{array}$} & \multicolumn{2}{|c|}{ With billing adjustment } & \multirow{3}{*}{$\begin{array}{c}\begin{array}{c}\text { Without } \\
\text { billing } \\
\text { adjustment }\end{array} \\
(\%) \\
\end{array}$} & \multirow{3}{*}{$\begin{array}{c}\begin{array}{c}\text { With } \\
\text { billing } \\
\text { adjustment }\end{array} \\
(\%)\end{array}$} \\
\hline & Actual $^{*}$ & MHEA & $\begin{array}{c}\text { MHEA } \\
\text { over- } \\
\text { prediction }\end{array}$ & MHEA & $\begin{array}{c}\text { MHEA } \\
\text { over- } \\
\text { prediction }\end{array}$ & & \\
\hline & (MBtu) & (MBtu) & $(\%)$ & (MBtu) & $(\%)$ & & \\
\hline All homes (43) & 14.0 & 39.9 & $185.9 \%$ & 26.2 & $87.8 \%$ & $35.0 \%$ & $53.2 \%$ \\
\hline $\begin{array}{l}\text { Two or more } \\
\text { energy } \\
\text { problems (11) }\end{array}$ & 17.1 & 72.6 & $325.0 \%$ & 38.0 & $122.6 \%$ & $23.5 \%$ & $44.9 \%$ \\
\hline $\begin{array}{l}\text { Only one or } \\
\text { no energy } \\
\text { problems (32) }\end{array}$ & 12.9 & 28.7 & $122.6 \%$ & 22.2 & $72.0 \%$ & $44.9 \%$ & $58.1 \%$ \\
\hline
\end{tabular}

*These values can also be found in Table 4.2.

As shown in Table 4.3, the overall results for the three studies are very consistent with one another: the audits overpredict annual pre-weatherization space-heating energy consumption, underpredict annual post-weatherization space-heating energy consumption, overpredict annual space-heating energy savings by about $200 \%$, and have realization rates below $60 \%$. Some differences in results among studies are indicated depending on the dataset chosen: MHEA's overprediction of annual preweatherization space-heating energy consumption may be greater than NEAT's, MHEA may more accurately estimate annual post-weatherization space-heating energy consumption compared to NEAT, and MHEA's realization rate may be less than that of NEAT's.

\subsection{ENHANCEMENTS TO IMPROVE ENERGY PREDICTION PERFORMANCE}

The ability of two features already built into MHEA (and NEAT) to improve MHEA's energy savings estimates were examined: MHEA's billing adjustment feature and MHEA's duct sealing evaluation option. In addition, the impact of modifying MHEA's heating system tune-up and setback thermostat measures were also investigated.

\subsubsection{Billing Adjustment Feature}

As discussed in Sect. 2.2, billing data can be entered into MHEA and used to adjust MHEA's annual space-heating energy savings estimates (no changes, per se, are made directly to MHEA's annual preand post-weatherization space-heating energy consumption estimates). To investigate the benefit of using MHEA's billing adjustment feature, billing data were entered as described in Sect. 2.2 for the 43 mobile homes in the refined dataset. The homes in the refined dataset were used to ensure that any observed benefits could not be attributed to homes having inaccurate data. MHEA was then rerun using the billing adjustment feature to obtain new energy savings estimates for these homes, and new comparisons were made between predicted and actual energy savings.

As shown in Table 4.4, use of the billing adjustment feature significantly improved MHEA's annual space-heating energy savings estimates and realization rates. MHEA's overprediction of annual space-heating energy savings for all 43 homes in the refined dataset was reduced by over $50 \%$ (from an overprediction of $185.9 \%$ to $87.8 \%$ ), with improvement occurring especially in homes with two or more major energy problems (overprediction was reduced from $325.0 \%$ to $122.6 \%$ ). The realization 


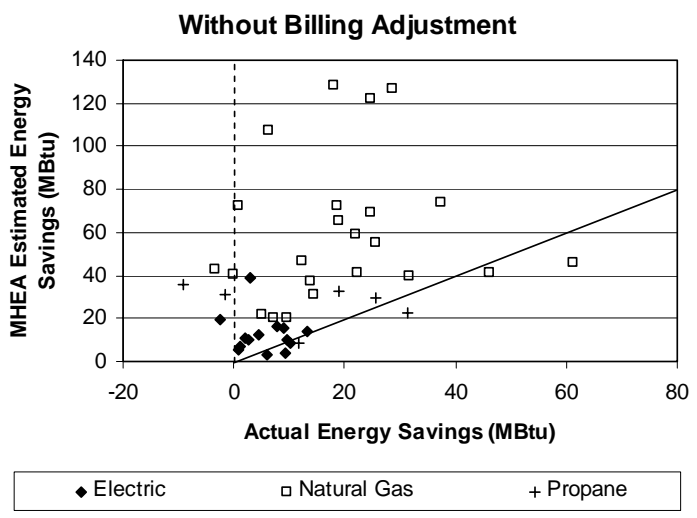

(a)

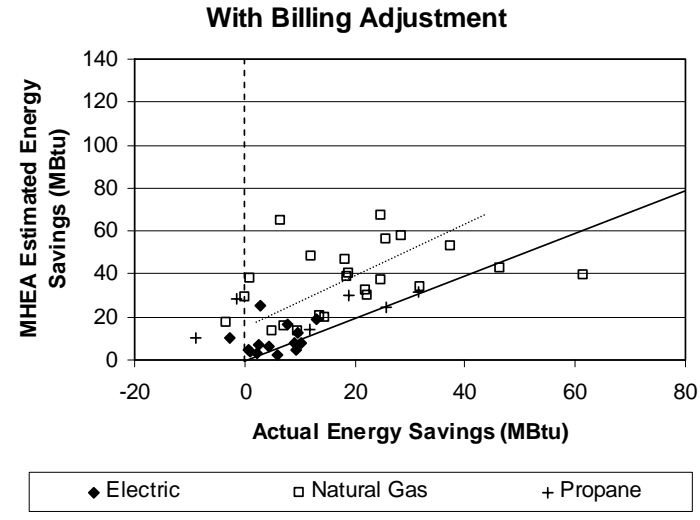

(b)

Figure 4.4. Comparison of MHEA's estimated annual space-heating energy savings to actual savings for homes in the refined dataset with and without the use of MHEA's billing adjustment feature. The solid lines are the lines of agreement between estimated and actual values.

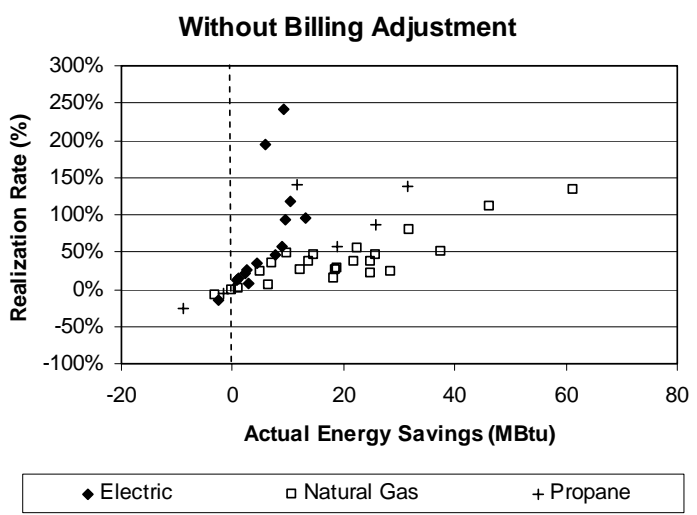

(a)

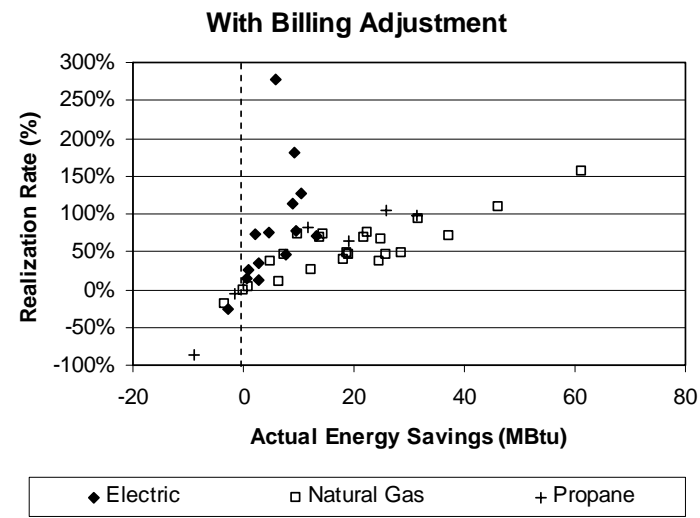

(b)

Figure 4.5. Realization rate as a function of actual annual space-heating energy savings for homes in the refined dataset with and without the use of MHEA's billing adjustment feature.

rate for MHEA increased from 35.0\% to 53.2\% for all 43 homes, with the realization rate doubling for homes with two or more major energy problems. Gettings found similar but somewhat smaller increases in realization rates when the billing adjustment feature was used in NEAT. Gettings reported that the realization rate increased from $59 \%$ to $66 \%$ for all homes in his study when the billing adjustment feature was used, and increased from $58 \%$ to $69 \%$ and from $51 \%$ to $57 \%$ for his two refined datasets.

Figures 4.4 and 4.5 show how the billing adjustment feature affected results for the individual homes in the refined dataset. Use of this feature significantly reduced MHEA's overestimation of annual space-heating energy savings in homes in which MHEA's estimated energy savings were significantly greater than actual (see Fig. 4.4). This is exemplified by the four homes in Fig. 4.4(a) with estimated annual space-heating energy savings greater than $100 \mathrm{MBtu}$. Conversely, use of the billing adjustment feature made little change in homes in which MHEA's estimated annual spaceheating energy savings were already consistent with actual savings (i.e., homes in Fig. 4.4 (a) that were already clustered around the line of equivalency). Although there are still homes in which MHEA overpredicts annual space-heating energy savings by $100 \%$ or more even after the billing 
adjustment feature is used (i.e., homes above the dotted line in Fig. 4.4(b)), Fig. 4.4(b) also shows that MHEA is estimating the energy savings of a majority of the homes with reasonable accuracy (i.e., homes below the dotted line in the figure) once the billing adjustment feature is used. Figure 4.5 shows that the realization rates for a majority of the homes in the refined dataset were between $0 \%$ and $50 \%$ before use of the billing adjustment feature, but about equal numbers of homes were between $0-50 \%$ and $50-100 \%$ after the billing adjustment feature was used.

\subsubsection{Tune-Up and Setback Thermostat Measures}

The tune-up measure used in this study's version of MHEA assumed that a tune-up would increase the steady-state efficiency of a space-heating system fired by natural gas or propane by 5 percentage points (e.g., from $72 \%$ to $77 \%$ ) regardless of the existing steady-state efficiency of the system. This measure has been changed in the most recent version of MHEA to be consistent with NEAT's more conservative algorithms for determining the efficiency improvements from a tune-up. The new algorithms assume that (a) a tune-up will increase the steady-state efficiency by 5 percentage points only if the existing efficiency is $70 \%$ or less, (b) no improvement will be obtained from a tune-up if the existing efficiency is $76 \%$ or greater, and (c) the percentage point increase from a tune-up is proportionally between $0 \%$ and $5 \%$ if the existing efficiency is between $76 \%$ and $70 \%$.

Although the potential benefits from reducing thermostat set points in the winter is not questioned, the savings from setback thermostats has recently been questioned because of the occupant interaction required to ensure their use once installed. In the version of MHEA used in this study, the savings from a setback thermostat were calculated in MHEA assuming that a $5^{\circ} \mathrm{F}$ setback occurred for 8 hours every day of the winter. To address the occupant interaction issue, two changes have been made to this measure in the most recent version of MHEA: (a) the measure now assumes that a setback occurs $5 / 7$ of the time (i.e., 5 days out of every week of the winter), and (b) recommendations now provided in MHEA training encourage users to assume a $3^{\circ} \mathrm{F}$ setback rather than a $5^{\circ} \mathrm{F}$ setback to better represent what might occur on average in homes over a winter.

Thirteen of the 43 homes in the refined dataset had one or the other of these two measures installed: a space-heating system tune-up was performed in 8 homes and a setback thermostat was installed in 5 homes. These measures, as configured in the version of MHEA used in the validation, likely overestimated the annual space-heating energy savings associated with their installation. To determine the impact that these two measures might have had on MHEA's overestimation of annual space-heating energy savings and subsequent low realization rates, MHEA was rerun on these homes after configuring MHEA to (a) simulate the new tune-up algorithms described above, and (b) assume very conservatively that there was no energy savings associated with the setback thermostat (essentially assuming that, if installed, occupants did not use the setback features of the new thermostat).

The overall effect of making these changes was positive but small. For the 43 homes in the refined dataset (see Table 4.5), MHEA's underprediction of annual post-weatherization space-heating energy consumption was reduced from $7.4 \%$ to $2.7 \%$, MHEA's overprediction of annual space-heating energy savings was reduced from $185.9 \%$ to $167.8 \%$, and the realization rate was improved from $35.0 \%$ to $37.3 \%$ (these changes did not impact MHEA's estimate of annual pre-weatherization spaceheating energy consumption). A greater impact can be observed in just the 13 homes that had one of these two measures installed: MHEA's underprediction of annual post-weatherization space-heating energy consumption was reduced from $18.5 \%$ to $5.9 \%$, MHEA's overprediction of annual spaceheating energy savings was reduced from $460.1 \%$ to $388.4 \%$, and the realization rate was improved from $17.9 \%$ to $20.5 \%$. Although these two measures are not the primary source of MHEA's overall 
Table 4.5. Results after modifying the tune-up and thermostat measures

\begin{tabular}{|l|c|c|c|c|c|c|}
\hline & \multicolumn{2}{|c|}{$\begin{array}{c}\text { MHEA's over- } \\
\text { prediction of annual } \\
\text { post-weatherization } \\
\text { Homes from the } \\
\text { refined dataset }\end{array}$} & $\begin{array}{c}\text { MHEA's over- } \\
\text { space-heating energy } \\
\text { consumption (\%) }\end{array}$ & $\begin{array}{c}\text { Mrediction of annual } \\
\text { space-heating energy } \\
\text { savings (\%) }\end{array}$ & \multicolumn{2}{|c|}{ Realization rate } \\
\cline { 2 - 7 } & Original & Modified & Original & Modified & Original & Modified \\
\hline All homes (43) & $-7.4 \%$ & $-2.7 \%$ & $185.9 \%$ & $167.8 \%$ & $35.0 \%$ & $37.3 \%$ \\
\hline $\begin{array}{l}\text { Homes with tune-up } \\
\text { and thermostat } \\
\text { measures installed (13) }\end{array}$ & $-18.5 \%$ & $-5.9 \%$ & $460.1 \%$ & $388.4 \%$ & $17.9 \%$ & $20.5 \%$ \\
\hline
\end{tabular}

overprediction of annual space-heating energy savings and low realization rates, the changes made to these two measures in the current version of MHEA will help improve MHEA's overall performance.

\subsubsection{Evaluate Duct Sealing Option}

MHEA provides four options for inputting information on the pre- and post-weatherization leakage of ducts: (a) whole-house blower door measurements before weatherization, after duct sealing but before any other air-leakage related weatherization work is performed, and post-weatherization; (b) wholehouse blower door measurements before and after weatherization with the ducts taped and untaped (i.e., the blower door subtraction method); (c) pre- and post-weatherization duct leakage measurements with a duct blower; and (d) pre- and post-weatherization pressure pan measurements (sum of the pressure pan measurements made on each supply register). Although the first three methods offer a more direct measurement of duct leakage, pressure pan measurements are the easiest measurements to make and made most routinely by weatherization crews in the field.

MHEA contains algorithms that allow duct leakage measurements, if entered, to be used in estimating the annual pre- and post-weatherization space-heating energy consumptions and energy savings associated with duct sealing. Simplistically, if no duct leakage measurements are entered, then MHEA assumes that there is no space-heating load induced on the home from duct leaks and, hence, no space-heating energy consumption associated with duct leaks. If duct leakage measurements are entered, then MHEA calculates the load induced by these leaks and the energy consumption due to these leaks. The net effect is, if duct leakage measurements are entered, then the space-heating energy consumption of the home will always be greater than if no measurements are entered.

Pressure pan readings before and after weatherization were available for 43 homes (not the same 43 homes in the refined dataset). These readings averaged $44.4 \mathrm{~Pa}$ (median value of $16.3 \mathrm{~Pa}$ ) before weatherization and 3.2 $\mathrm{Pa}$ (median value of $3.1 \mathrm{~Pa}$ ) after weatherization. Use of MHEA's "evaluate duct sealing" option increased MHEA's annual pre-weatherization space-heating energy consumption estimates on average by 15.6 MBtu (see Table 4.6) but had little effect on post-weatherization estimates because the ducts were sealed and the duct leakage was very low following weatherization.

Results presented in Sect. 4.1.2 and 4.1.3 have shown that MHEA overpredicts annual preweatherization space-heating energy consumption. Results presented in this section indicate that the "evaluate duct sealing" option will not improve MHEA's ability to predict annual pre-weatherization space-heating energy consumption or annual space-heating energy savings. In fact, in eight homes 
Table 4.6. Results with and without duct sealing evaluation

\begin{tabular}{|l|c|c|}
\hline \multirow{2}{*}{} & \multicolumn{2}{|c|}{ Annual space-heating energy consumption } \\
\cline { 2 - 3 } & Pre-weatherization & Post-weatherization \\
\cline { 2 - 3 } & (MBtu) & (MBtu) \\
\hline Without duct sealing evaluation & 82.0 & 50.5 \\
\hline With duct sealing evaluation & 97.6 & 51.1 \\
\hline
\end{tabular}

with total pressure pan readings greater than $75 \mathrm{~Pa}$, MHEA already overpredicted annual preweatherization space-heating energy consumption in six of them when the duct sealing evaluation option was not used; in the other two homes, MHEA overestimated annual pre-weatherization spaceheating energy consumption when the duct sealing evaluation option was used by about the same amount that it underestimated pre-weatherization energy consumption when the option was not used.

\subsection{INSULATION MATERIAL QUANTITIES}

To estimate the energy savings from floor, attic, and wall insulation, MHEA was programmed to estimate the amount of insulation needed based on the existing level of insulation, the various configurations of these envelope areas, and the recommended methods for insulating these areas. The amount of insulation needed for each envelope area is printed out on MHEA's list of recommended measures. Knowing the accuracy of these estimates is important because (a) they affect the accuracy of MHEA's energy savings estimates and cost-effectiveness calculations, and (b) even more importantly, they provide guidance to the weatherization crews on whether they are insulating these areas properly (i.e., if they are using the right technique such that the right amount of insulation is installed at the proper density).

Fiberglass insulation was used by all the agencies when insulating these envelope areas. The insulation approaches used by the agencies and assumed within MHEA are as follows:

- Floor wing - In the outside, or wing, sections of the floor, the existing insulation blanket is usually fastened to the underside of the floor joist creating a cavity between the top of the insulation and the subfloor. This cavity is insulated by blowing in loose-fill fiberglass insulation at high density until the cavity is full.

- Floor belly - Three types of center, or belly, sections of the floor were encountered in the validation: flat, rounded, and square. In a flat belly (the usual configuration when the floor joists run the length of the mobile home), the existing insulation blanket is fastened to the underside of the floor joist creating a cavity between the top of the insulation and the subfloor (the ducts run just beneath the subfloor parallel to the floor joists). A flat belly is insulated just like the floor wing: loose-fill fiberglass insulation is blown at high density into the cavity between the insulation blanket and the subfloor until the cavity is full. In a rounded belly (the usual configuration when the floor joists run the width of the mobile home), the ducts are hung below the floor joists and the existing insulation blanket is draped below the ducts between the I-beams supporting the floor. A rounded belly is insulated by blowing about 8 in. of loose-fill fiberglass insulation loosely on top of the insulation blanket in the main part of the belly, but at high density near the perimeter (the rounded belly cavity is not packed full of insulation like a flat belly or wing area). The existing insulation blanket may be re-strapped prior to blowing in the insulation to make the belly cavity smaller and ensure that the weight of the fiberglass can be supported. A square belly is similar to a rounded belly in that the existing insulation blanket is below the ducts, but the insulation blanket or other material is 
stretched across the bottom of the I-beams in a square belly rather than being draped from the top of the I-beams. A square belly is insulated in the same manner as a rounded belly, by loosely blowing about 9 in. of loose-fill fiberglass insulation on top of the existing blanket.

- Attic - Three types of attics were encountered in the study: flat, bowstring, and pitched. In a flat attic, a flat roof is installed on top of the ceiling joists, which creates a cavity between the ceiling of the home and the roof. A flat attic is insulated by blowing loose-fill fiberglass insulation into the cavity between the ceiling and the roof at high density so that the cavity is full. A bowstring roof is curved, such that the height in the center of the attic is usually about $6-14$ in. A bowstring attic is insulated by blowing loose-fill fiberglass insulation into the cavity at high density such that the cavity space is completely filled. A pitched roof looks like the roofs of site-built homes and can be 24 in. or more in the center. In a pitched attic, fiberglass insulation is loosely blown into the attic space until the desired depth is obtained.

- Walls - The exterior walls of mobile homes can be insulated using batt or loose-fill insulation. The preferred method (and the method used in the mobile homes insulated in this study) is to loosen the bottom of the siding and stuff an R-11 fiberglass batt into the cavity space using a flexible sheet of Plexiglas as a stuffer. Loose-fill fiberglass insulation can also be installed at high density using a fill tube.

Information on the amount of insulation installed in the floor, attic, and wall were provided by the agencies on 42, 27, and 7 mobile homes, respectively. As shown in Table 4.7, MHEA consistently underestimated the amount of insulation installed, on average, in the homes, although this underestimate was rather small (less than 10\%) for both attic and wall insulation, and for insulation installed in floors with flat bellies. For floors with a rounded belly, MHEA underpredicted the amount of insulation actually installed by $22.3 \%$.

Figure 4.6 shows that MHEA's estimates of the amount of insulation needed were within $+/-25 \%$ in most homes. The greatest deviation may be three homes in which more than $700 \mathrm{lb}$ of insulation were installed but MHEA predicted that less than $500 \mathrm{lb}$ would be needed (see Fig. 4.6 (a)). It should be noted that these three homes were weatherized by agencies from three different states.

Table 4.7. Amounts of fiberglass insulation installed

\begin{tabular}{|c|c|c|c|c|c|}
\hline \multirow{2}{*}{$\begin{array}{c}\text { Envelope area and } \\
\text { configuration }\end{array}$} & $\begin{array}{c}\text { Number of } \\
\text { mobile } \\
\text { homes }\end{array}$ & $\begin{array}{c}\text { Actually } \\
\text { installed }\end{array}$ & $\begin{array}{c}\text { MHEA } \\
\text { estimate }\end{array}$ & Difference & $\begin{array}{c}\text { Percentage } \\
\text { difference }\end{array}$ \\
\cline { 3 - 6 } & Floor & $469.4 \mathrm{lb}$ & $375.2 \mathrm{lb}$ & $-94.2 \mathrm{lb}$ & $-20.1 \%$ \\
\hline All configurations & 42 & $333.0 \mathrm{lb}$ & $314.0 \mathrm{lb}$ & $-19.0 \mathrm{lb}$ & $-5.7 \%$ \\
\hline Flat belly & 8 & $501.5 \mathrm{lb}$ & $389.7 \mathrm{lb}$ & $-111.9 \mathrm{lb}$ & $-22.3 \%$ \\
\hline Rounded belly & 33 & $197.8 \mathrm{lb}$ & $197.8 \mathrm{lb}$ & $0.0 \mathrm{lb}$ & $0.0 \%$ \\
\hline Square belly & 1 & & & $-26.4 \mathrm{lb}$ & $-6.6 \%$ \\
\hline Attic & 27 & $397.3 \mathrm{lb}$ & $370.9 \mathrm{lb}$ & $-26.4 \mathrm{lb}$ & $-6.8 \%$ \\
\hline All configurations & 27 & $386.1 \mathrm{lb}$ & $359.7 \mathrm{lb}$ & $-31.4 \mathrm{lb}$ & $-7.6 \%$ \\
\hline Flat & 2 & $414.8 \mathrm{lb}$ & $383.4 \mathrm{lb}$ & $0.0 \mathrm{lb}$ & $0.0 \%$ \\
\hline Bowstring & 21 & $310.8 \mathrm{lb}$ & $310.8 \mathrm{lb}$ & \\
\hline Pitched & 4 & $686.4 \mathrm{ft}^{2}$ & $621.1 \mathrm{ft}^{2}$ & $-65.3 \mathrm{ft}^{2}$ & $-9.5 \%$ \\
\hline
\end{tabular}




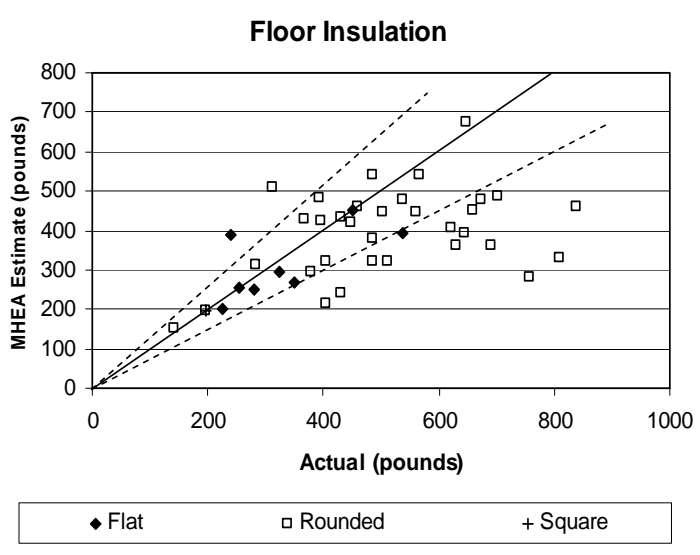

(a)

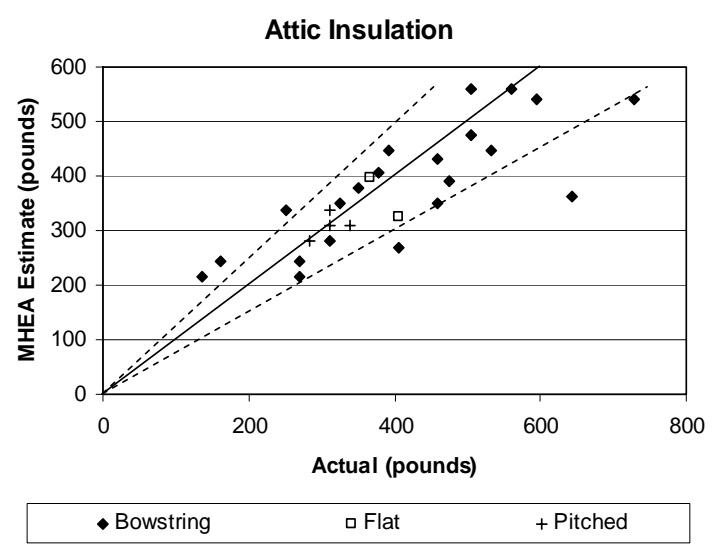

(b)

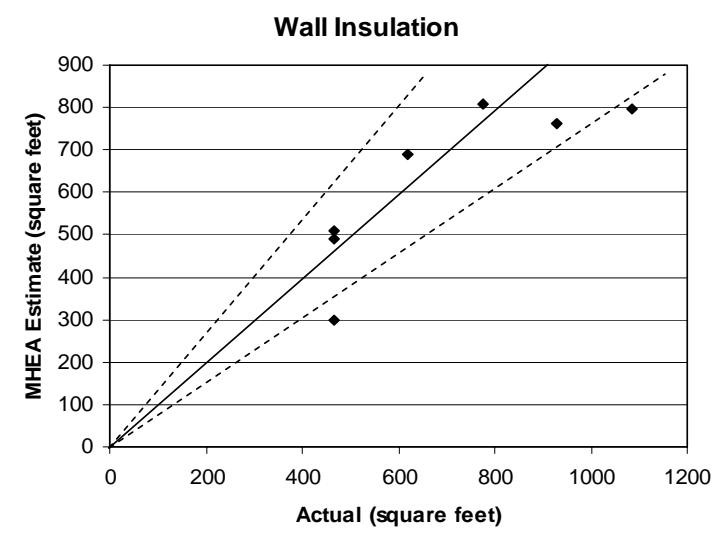

(c)

Figure 4.6. Comparison of MHEA's estimates of the amount of insulation needed to insulate the envelope area to the amount the weatherization crews actually installed. The solid lines are the lines of agreement between estimated and actual values. The dashed lines represent estimates $25 \%$ above and below actual.

MHEA's underestimates of the amount of insulation installed could be because MHEA is incorrectly calculating the amount of insulation needed to insulate these envelope areas, or because crews are installing more insulation in the envelope areas than needed. The latter may be especially true for rounded bellies because the tendency on the part of crews is to deviate from training and overfill the available volume in a rounded belly (similar behavior might be expected in square bellies, but the sample size of one for this type of belly does not allow any conclusions to be drawn from the data). Better agreement between estimated and actual amounts of insulation installed may occur in flat bellies, flat and bowstring attics, and walls because these cavity spaces are all completely filled with insulation if recommended insulation practices are followed, so there is less room for error. 


\section{CONCLUSIONS AND RECOMMENDATIONS}

\subsection{CONCLUSIONS}

Based on the results of this validation study, MHEA overpredicts the annual space-heating energy savings of weatherization measures to be installed in mobile homes, which leads to low realization rates. On average, MHEA overpredicts annual space-heating energy savings by about $200 \%$ and achieves a realization rate of about $35 \%$ whether all mobile homes are considered or just those homes with quality billing data and supplemental electric space-heating data. Overpredictions of annual space-heating energy savings and low realization rates occur independent of the primary spaceheating fuel (electricity, natural gas, or propane) and in both moderate and cold climates.

Individually, MHEA overpredicts the annual space-heating energy savings in almost every mobile home, and the realization rate is less than $100 \%$ in most homes.

MHEA's large overprediction of annual pre-weatherization space-heating energy consumption is the primary cause of its overprediction of annual space-heating energy savings. MHEA overpredicts the annual pre-weatherization consumption in the majority of the mobile homes by about $33 \%$, on average. MHEA has particular trouble with mobile homes that have several major energy deficiencies associated with the thermal envelope of the home or the operation of the space-heating system; it overestimates the annual pre-weatherization space-heating energy consumption of these homes by around $60 \%$, on average.

MHEA's annual post-weatherization space-heating energy consumptions estimates are just a secondary cause (if any) of its overprediction of annual space-heating energy savings. MHEA's annual post-weatherization space-heating energy consumption estimates are considerably more accurate, on average, than its pre-weatherization estimates. The annual post-weatherization spaceheating energy consumption estimates flip from underpredicting to overpredicting (usually within the range of $+/-10 \%$ ) depending on factors such as the primary space-heating fuel, number of major energy efficiency problems that were originally associated with the home, and the quality of the data used in the analyses. This, combined with how well MHEA predicted annual pre-weatherization space-heating energy consumption based on these same factors, may slightly contribute to overpredictions of annual space-heating energy savings.

MHEA's overprediction of annual space-heating energy savings was cut in half, from $185.9 \%$ to $87.8 \%$, and its realization rate improved by about $50 \%$, from $35.0 \%$ to $53.2 \%$, using MHEA's built-in billing adjustment feature. This feature adjusts MHEA's annual space-heating energy savings estimates based on a comparison between its annual pre-weatherization space-heating energy consumption estimate and billing data. The adjustment had the greatest impact in those homes with the greatest overprediction of annual space-heating energy savings and lowest realization rates (e.g., homes with two or more major energy efficiency problems). Minor changes already made to two of MHEA's weatherization measures - space-heating system tune-up and setback thermostat - have already improved MHEA's prediction capabilities.

The use of MHEA's “evaluate duct sealing” option does not improve MHEA's prediction capabilities at this time. MHEA does not presently assume any default heat loss from duct leakage. Therefore, when the "evaluate duct sealing" option is used, MHEA calculates a higher heating load for the home because of the added duct losses, which only adds to the overprediction of annual pre-weatherization space-heating energy consumption that MHEA is already experiencing. 
Finally, MHEA's estimates for the amount of insulation to be installed in floors, attics, and walls appear to be within reason. Generally, MHEA underpredicts the amount of insulation needed by no more than $10 \%$. The primary exception is homes with rounded bellies. For these, MHEA underpredicted the amount of insulation actually installed by about $20 \%$, although it is not known whether MHEA underpredicted the needed amount or if crews just installed more insulation than necessary.

\subsection{RECOMMENDATIONS}

In order to improve the accuracy of MHEA's annual space-heating energy savings estimates and realization rate, the cause of MHEA's overprediction of annual pre-weatherization space-heating energy consumption should be further investigated and corrected. Because MHEA's overpredictions are larger in homes with several major energy deficiencies, this investigation should focus first on factors that might be associated with such homes. For example, the variable-based degree-day method used in MHEA should be examined because the number of degree days for a given home varies based on the overall $\mathrm{U}$-value of the home. In addition, the R-value of building components when there is little or no insulation present and/or when the thermal integrity of the component is poor should be looked at closely. Because MHEA does not presently assume any default heat loss from duct leakage, corrections should be made such that MHEA slightly underpredicts annual pre-weatherization spaceheating energy consumption so that its predictions are improved when the option to evaluate duct sealing is utilized (which increases pre-weatherization heating load and, hence, annual space-heating energy consumption).

Once MHEA's overprediction of annual pre-weatherization space-heating energy consumption is corrected, then the accuracy of MHEA's annual post-weatherization space-heating energy consumption estimates and estimates for individual weatherization measures should be rechecked.

While the goal should be to make MHEA as accurate as possible, unrealistic expectations should not be placed on MHEA. Small inaccuracies associated with estimating annual pre- and postweatherization space-heating energy consumptions can lead to larger inaccuracies associated with annual space-heating energy savings and realization rates. In order for audit programs such as MHEA to remain easily useable by and useful to weatherization crews and weatherization programs, some inaccuracies must be expected and tolerated.

Although MHEA's billing adjustment feature improved its annual space-heating energy savings estimates, alternative methods of making the correction should be investigated. The present method of modifying the annual space-heating energy savings estimates based on the ratio of predicted to actual annual pre-weatherization space-heating energy consumption limits the amount of correction that can occur. A method that also considers the annual post-weatherization space-heating energy consumption estimate and how it compares to the actual annual pre-weatherization space-heating energy consumption based on billing data may provide greater capabilities.

Weatherization crews should be trained to use MHEA's estimates for the amounts of insulation that need to be installed in floors, attics, and walls as guidance during the insulation process. For example, if 20 bags of insulation are needed to blow a bowstring attic, then 5 bags should be used when the first $25 \%$ of the attic is insulated. MHEA's estimates should also be used as a quality assurance check once the work is completed to ensure that the crews are using the proper techniques to install the proper amounts of insulation. 
Finally, the following recommendations are offered to current users of MHEA in the interim period before the changes recommended above can be made:

- Do not enter into MHEA insulation thicknesses of 1 in. or less and especially zero ( 0 in.) unless such low levels have been verified through visual inspection of several parts of the envelope area in question. Such values should not be entered to account for existing floor insulation that is ripped and/or missing in some locations. Use a thickness of 1.25 in. or 1.5 in. for existing insulation blankets or batts that appear to be about 1 in. thick.

- Use MHEA's billing adjustment feature to develop a list of recommended measures based on adjusted energy savings if possible, especially in mobile homes that have two or more of the following major energy deficiencies: 1 in. or less of insulation in either the ceiling, floor, wall, or any part of an addition; a majority of the windows being single-pane; an air leakage rate greater than $3000 \mathrm{cfm} 50$; and space-heating steady-state efficiency of less than $70 \%$.

- Do not use MHEA's “evaluate duct sealing” option at this time (although certainly seal all duct leaks and use diagnostics as appropriate to find leakage sites and quantify improvements). 


\section{REFERENCES}

Brown, M. A., L. G. Berry, R. Balzer, and E. Faby. 1993. National Impacts of the Weatherization Assistance Program in Single-Family and Small Multifamily Dwellings. ORNL/CON-326. Oak Ridge National Laboratory, Oak Ridge, TN. May. [http://weatherization.ornl.gov/pdf/ORNL_CON326.pdf].

Dalhoff, G. 1996. An Evaluation of the Performance of the NEAT Audit as Implemented in the Iowa Weatherization Program. Dalhoff and Associates, Verona, WI. October 29.

DOE. 2003. Weatherization Program Notice 03-6. September 26. [www.waptac.org/sp.asp?id=7163].

Fels, M., K. Kissock, M. Marean, and C. Reynolds. 1995. PRISM Advanced Version 1.0 User's Guide. Princeton University, Center for Energy and Environmental Studies, Princeton, NJ.

[http://www.princeton.edu/ marean].

Gettings, M. B. 2006. The Weatherization Assistant Users Manual for Administrative Features (Version 8). ORNL/TM-2005/236. Oak Ridge National Laboratory, Oak Ridge, TN. January. [www.waptac.org/sp.asp?id=8452].

Gettings, M. B., L. G. Berry, M. A. Beyer, and J. B. Maxwell. 1998. Validation of the National Energy Audit (NEAT) with Data from a Gas Utility Low-Income Residential Weatherization Program in New York State. ORNL/CON-457. Oak Ridge National Laboratory, Oak Ridge, TN. January. [http://www.ornl.gov/ webworks/cppr/y2001/rpt/96198.pdf].

Judkoff, R. and J. Neymark. 1995. Home Energy Rating System Building Energy Simulation Test (HERS BESTEST), Volume 2: Tier 1 and Tier 2 Tests Reference Results. NREL/TP-472-7332b. National Renewable Energy Laboratory, Golden, CO. November.

[http://www.nrel.gov/docs/legosti/fy96/7332b.pdf].

Khawaja, M. S., A. Lee, M. Perussi, E. Morris, and A. West. 2006. Ohio Home Weatherization Assistance Program Impact Evaluation. Quantec, LLC, Portland, OR. Prepared for the Ohio Office of Energy Efficiency, Columbus, OH. July.

[http://www.odod.state.oh.us/cms/uploadedfiles/CDD/OEE/200463\%20Impact\%20Eval\%20Final\%2 0070606.pdf].

National Climatic Data Center. 1981. Typical Meteorological Year User’s Manual. TD-9734. National Climatic Data Center, U.S. Department of Commerce, Asheville, NC. May.

[http://lwf.ncdc.noaa.gov/oa/ncdc.html]. 


\section{ORNL/CON-501}

\section{INTERNAL DISTRIBUTION}

1-10. M. T. Eady

11. J. F. Eisenberg

12. M. B. Gettings
13-23. M. P. Ternes

24. ORNL Office of Technical Information and Classification

\section{EXTERNAL DISTRIBUTION}

25. Mr. Thomas Andrews, Ohio Energy Office, $26^{\text {th }}$ Floor, 77 South High Street, Columbus, OH 43215-6130

26. Mr. Dennis Biddle, Ohio Energy Office, $26^{\text {th }}$ Floor, 77 South High Street, Columbus, OH 43215

27. Mr. James Childs, U.S. Department of Energy, EE-2K/Forrestal Building, 1000 Independence Avenue, S.W., Washington, DC 20585

28. Mr. Robert DeSoto, U.S. Department of Energy, Golden Field Office, MS 1501, 1617 Cole Boulevard, Golden, CO 80401

29. Mr. Ted Koenig, Missouri Department of Natural Resources, Energy Center, 1659 East Elm, Jefferson City, MO 65102-0176

30. Mr. Tim Lenahan, Ohio Energy Office, $26^{\text {th }}$ Floor, 77 South High Street, Columbus, OH 43215

31. Mr. Nick Milano, Ohio Energy Office, $26^{\text {th }}$ Floor, 77 South High Street, Columbus, OH 43215

32. Mr. Alex Moore, D\&R International, Ltd., Suite 500, 1300 Spring Street, Silver Spring, MD 20910

33. Mr. Michael Peterson, U.S. Department of Energy, Golden Field Office, MS 1502, 1617 Cole Boulevard, Golden, CO 80401

34. Mr. Charlie Richardson, Longs Peak Energy Conservation, Suite J, 2450 Central Avenue, Boulder, CO 80301

35. Mr. Gregg Riley, King County Housing Authority, $1545565^{\text {th }}$ Avenue South, Seattle, WA 98188

36. Mr. Bob Scott, West Virginia Governor's Office of Economic Opportunity, $3^{\text {rd }}$ Floor, 950 Kanawha Boulevard East, Charleston, WV 25301

37. Mr. Skip Sears, Missouri Ozarks Community Action, P. O. Box 69, Richland, MO 65556

38. Mr. Cal Steiner, North Dakota Department of Commerce, 1600 East Century Avenue, Bismarck, ND 58503

39. Mr. Geoff Wilcox, Vermont Office of Economic Opportunity, 103 South Main Street, Waterbury, VT 05671 